\title{
Reactions in the Al-H-Cl System Studied by ab Initio Molecular Orbital and Density Functional Methods
}

\author{
Mark T. Swihart* \\ Department of Chemical Engineering, University at Buffalo (SUNY), Buffalo, New York 14260-4200
}

\section{Laurent Catoire}

Laboratoire de Combustion et Systèmes Réactifs (LCSR), CNRS, and University of Orleans, 1C, av. de la recherche scientifique, 45071 Orleans Cedex 2, France

Received: September 28, 2000

\begin{abstract}
High-level ab initio quantum chemical calculations have been used to investigate possible reactions in the $\mathrm{Al}-\mathrm{H}-\mathrm{Cl}$ system. Transition states or barrierless reaction paths have been identified for essentially all feasible reactions in this system involving a single aluminum atom. Structures, energies, and vibrational frequencies for reactants, products, and transition states in this system are presented. These results provide a basis for the estimation of reaction rate parameters for this system using transition state theory and related unimolecular reaction rate theories and thereby construct a reaction mechanism useful for detailed chemical kinetic modeling of aluminum combustion in $\mathrm{HCl}$ and chemical vapor deposition using $\mathrm{AlCl}_{3}$ in $\mathrm{H}_{2}$. In the few cases where previous experimental or theoretical results have been published, the present work is consistent with previous work.
\end{abstract}

\section{Introduction}

The gas-phase chemistry of the $\mathrm{Al}-\mathrm{H}-\mathrm{Cl}$ system is of interest in at least two contexts: (1) $\mathrm{AlCl}_{3}$ can be used as a precursor for the deposition of aluminum-containing materials by CVD processes, often in the presence of $\mathrm{H}_{2}$, and (2) aluminum is added to solid rocket propellant where it can react exothermically with the products of combustion of other fuels, including $\mathrm{HCl}, \mathrm{H}_{2} \mathrm{O}, \mathrm{CO}$, and $\mathrm{CO}_{2}$. However, there is very little experimental information on elementary reactions in this system, or even on the thermochemistry of many of the species. To the best of our knowledge, no experiments concerning the combustion of $\mathrm{Al}$ particles in pure $\mathrm{HCl}$ have been reported in the open literature. A few reactions in this system have been studied experimentally ${ }^{1-3}$ or theoretically, ${ }^{4,5}$ but most of the possible reactions remain uninvestigated. We are using computational chemistry to explore possible reactions in this system and to calculate rate parameters for elementary gas-phase reactions. In recently published work, ${ }^{6}$ we used high-accuracy molecular orbital calculations to establish the thermochemistry of compounds in this system and of some oxygen, nitrogen, and carboncontaining aluminum compounds. On the basis of these results, we have identified possible reactions in the $\mathrm{Al}-\mathrm{H}-\mathrm{Cl}$ system and are applying transition state theory and unimolecular reaction rate theories to calculate rate parameters for these reactions. Molecular orbital calculations of transition state properties and reaction paths serve as inputs to these rate parameter calculations. For elementary reactions with an activation barrier, we have located transition states and computed their energies using high-accuracy compound methods for energy calculations, including the G-2, CBS-Q, and CBS-RAD methods. For simple bond-breaking reactions without an activation barrier in the exothermic direction, we have used density

* Corresponding author. E-mail: swihart@eng.buffalo.edu. Tel: (716) 645-2911, x. 2205. Fax: (716) 645-3822. functional theory calculations to evaluate the energy as a function of the breaking bond length. Conventional transition state theory, with tunneling corrections as necessary, is used to compute the rate parameters for bimolecular reactions. Unimolecular and recombination reactions are treated using RRKM theory and master equation calculations. Results of the molecular orbital calculations are presented in this paper, while computed kinetic parameters will be presented separately. ${ }^{7}$

\section{Computational Methods}

Four high-accuracy ab initio models for computational thermochemistry were applied to the aluminum compounds and transition states studied here. The first method was based on density functional theory calculations using the B3LYP functional. This functional employs Becke's gradient-corrected exchange functional, ${ }^{8}$ the Lee-Yang-Parr correlational functional, ${ }^{9}$ and three parameters fit to the original G-2 test set. ${ }^{10}$ The geometry optimization and frequency calculations for this method used the 6-31G(d) basis set. The energy at that geometry was then calculated using the $6-311+\mathrm{G}(3 \mathrm{df}, 2 \mathrm{p})$ basis set. The second method used here was the CBS-Q complete basis set method of Ochterski et al. ${ }^{11}$ This method employs the asymptotic convergence of pair natural orbital expansions to extrapolate to the second-order Møller-Plesset (MP2) complete basis set limit. The higher-order contributions are then evaluated using smaller basis sets. The third method used was the Gaussian-2 (G-2) model. This method approximates a quadratic configuration interaction calculation with a large basis set (QCISD(T)/6-311+G(3df,2p)) by combining a series of smaller calculations and assuming the additivity of several components of the energy. ${ }^{12-14}$ All of the calculations were carried out using the Gaussian 94 computer program. ${ }^{15}$

Many of the species and transition states considered here have open-shell ground-state electronic configurations (one or more 
TABLE 1: Reactant, Product, and Transition-State Energies

\begin{tabular}{|c|c|c|c|c|c|c|c|c|}
\hline \multirow[b]{2}{*}{ species } & \multicolumn{4}{|c|}{ total energy (hartrees) ${ }^{a}$} & \multicolumn{4}{|c|}{ relative energy $\left(\mathrm{kcal} \mathrm{mol}^{-1}\right)^{b}$} \\
\hline & $\mathrm{B} 3 \mathrm{LYP}^{c}$ & CBS-Q & G-2 & CBS-RAD & $\mathrm{B} 3 \mathrm{LYP}^{c}$ & CBS-Q & G-2 & CBS-RAD \\
\hline $\mathrm{AlH}$ & -243.001271 & -242.542997 & -242.546190 & -242.544989 & 0.0 & 0.0 & 0.0 & 0.0 \\
\hline $\mathrm{Al}^{d}+\mathrm{H}$ & -242.888857 & -242.428515 & -242.430950 & -242.428486 & 70.5 & 71.8 & 72.3 & 73.1 \\
\hline $\mathrm{AlCl}$ & -702.741598 & -701.808146 & -701.800168 & -701.807884 & 0.0 & 0.0 & 0.0 & 0.0 \\
\hline $\mathrm{Al}^{d}+\mathrm{Cl}^{d}$ & -702.555447 & -701.611935 & -701.607923 & -701.611879 & 116.8 & 123.1 & 120.6 & 123.0 \\
\hline $\mathrm{AlH}_{2}$ & -243.580957 & -243.117319 & -243.118965 & -243.117100 & 0.0 & 0.0 & 0.0 & 0.0 \\
\hline $\mathrm{Al}^{d}+\mathrm{H}_{2}$ & -243.557108 & -243.095127 & -243.097652 & -243.095061 & 15.0 & 13.9 & 13.4 & 13.8 \\
\hline $\mathrm{AlH}+\mathrm{H}$ & -243.503427 & -243.042815 & -243.046190 & -243.044807 & 48.7 & 46.8 & 45.7 & 45.4 \\
\hline $\mathrm{AlH}_{2} \leftrightarrow \mathrm{Al}+\mathrm{H}_{2} \mathrm{SP}^{e}$ & -243.517765 & & & -243.051663 & 39.7 & & & 41.1 \\
\hline $\mathrm{AlHCl}$ & -703.300791 & -702.362308 & -702.353346 & -702.362027 & 0.0 & 0.0 & 0.0 & 0.0 \\
\hline $\mathrm{AlCl}+\mathrm{H}$ & -703.243754 & -702.307964 & -702.300168 & -702.307702 & 35.8 & 34.1 & 33.4 & 34.1 \\
\hline $\mathrm{Al}^{d}+\mathrm{HCl}$ & -703.218823 & -702.276112 & -702.271471 & -702.276047 & 51.4 & 54.1 & 51.4 & 54.0 \\
\hline $\mathrm{AlH}+\mathrm{Cl}^{d}$ & -703.171015 & -702.227233 & -702.224161 & -702.229198 & 81.4 & 84.8 & 81.1 & 83.4 \\
\hline $\mathrm{Al}+\mathrm{HCl} \leftrightarrow \mathrm{AlCl}+\mathrm{H} \mathrm{SP}^{e}$ & -703.219293 & -702.274135 & -702.262908 & -702.269822 & 51.1 & 55.3 & 56.8 & 57.9 \\
\hline $\mathrm{Al}+\mathrm{HCl} \leftrightarrow \mathrm{AlHCl} \mathrm{SP} e$ & -703.226833 & -702.284301 & -702.275298 & -702.283424 & 46.4 & 49.0 & 49.0 & 49.3 \\
\hline $\mathrm{Al}-\mathrm{HCl}$ complex & -703.226503 & -702.281895 & -702.276027 & -702.281485 & 46.6 & 50.5 & 48.5 & 50.5 \\
\hline $\mathrm{Al}-\mathrm{ClH}$ complex & & -702.279034 & -702.273953 & -702.278719 & & 52.3 & 49.8 & 52.3 \\
\hline $\mathrm{AlCl}_{2}$ & -1163.016482 & -1161.604454 & -1161.585244 & -1161.604014 & 0.0 & 0.0 & 0.0 & 0.0 \\
\hline $\mathrm{AlCl}+\mathrm{Cl}^{d}$ & -1162.911342 & -1161.492382 & -1161.478139 & -1161.492093 & 66.0 & 70.3 & 67.2 & 70.2 \\
\hline $\mathrm{Al}^{d}+\mathrm{Cl}_{2}$ & -1162.810259 & -1161.388648 & -1161.373501 & -1161.388444 & 129.4 & 135.4 & 132.9 & 135.3 \\
\hline $\mathrm{AlH}_{3}$ & -244.213664 & -243.750511 & -243.753945 & -243.750143 & 0.0 & 0.0 & 0.0 & 0.0 \\
\hline $\mathrm{AlH}+\mathrm{H}_{2}$ & -244.171338 & -243.709087 & -243.712552 & -243.711042 & 26.6 & 26.0 & 26.0 & 24.5 \\
\hline $\mathrm{AlH}_{2}+\mathrm{H}$ & -244.083113 & -243.617137 & -243.618965 & -243.616918 & 81.9 & 83.7 & 84.7 & 83.6 \\
\hline $\mathrm{AlH}+\mathrm{H}_{2} \leftrightarrow \mathrm{AlH}_{3} \mathrm{SP}^{e}$ & -244.115870 & & & -243.652045 & 61.4 & & & 61.6 \\
\hline $\mathrm{AlH}_{2} \mathrm{Cl}$ & -703.931955 & -702.994383 & -702.987800 & -702.993963 & 0.0 & 0.0 & 0.0 & 0.0 \\
\hline $\mathrm{AlCl}+\mathrm{H}_{2}$ & -703.911664 & -702.974236 & -702.966530 & -702.973937 & 12.7 & 12.6 & 13.3 & 12.6 \\
\hline $\mathrm{AlH}+\mathrm{HCl}$ & -703.833052 & -702.890072 & -702.886371 & -702.892028 & 62.1 & 65.5 & 63.6 & 64.0 \\
\hline $\mathrm{AlHCl}+\mathrm{H}$ & -703.802947 & -702.862126 & -702.853346 & -702.861845 & 81.0 & 83.0 & 84.4 & 82.9 \\
\hline $\mathrm{AlH}_{2}+\mathrm{Cl}^{d}$ & -703.749363 & -702.800217 & -702.795598 & -702.799971 & 114.6 & 121.8 & 120.6 & 121.7 \\
\hline $\mathrm{AlH}_{2} \mathrm{Cl} \leftrightarrow \mathrm{AlH}$ & -703.824547 & & & -702.878649 & 67.4 & & & 72.4 \\
\hline $\mathrm{AlH}_{2} \mathrm{Cl} \leftrightarrow \mathrm{AlCl}$ & -703.814280 & & & -702.875799 & 73.8 & & & 74.1 \\
\hline $\mathrm{AlHCl}+\mathrm{H} \leftrightarrow \mathrm{AlH}+\mathrm{HCl} \mathrm{SP}{ }^{e}$ & -703.799626 & & & -702.856708 & 83.0 & & & 86.1 \\
\hline $\mathrm{AlHCl}_{2}$ & -1163.647904 & -1162.236874 & -1162.220233 & -1162.236393 & 0.0 & 0.0 & 0.0 & 0.0 \\
\hline $\mathrm{AlCl}+\mathrm{HCl}$ & -1163.573379 & -1162.155221 & -1162.140349 & -1162.154923 & 46.8 & 51.2 & 50.1 & 51.1 \\
\hline $\mathrm{AlCl}_{2}+\mathrm{H}$ & -1163.518638 & -1162.104272 & -1162.085244 & -1162.103832 & 81.1 & 83.2 & 84.7 & 83.2 \\
\hline $\mathrm{AlHCl}+\mathrm{Cl}^{d}$ & -1163.470535 & -1162.046544 & -1162.031317 & -1162.046236 & 111.3 & 119.4 & 118.5 & 119.3 \\
\hline $\mathrm{AlH}+\mathrm{Cl}_{2}$ & -1163.424488 & -1162.002608 & -1161.988401 & -1162.004425 & 140.2 & 147.0 & 145.5 & 145.6 \\
\hline $\mathrm{AlCl}+\mathrm{HCl} \leftrightarrow \mathrm{AlCl}_{2}+\mathrm{H} \mathrm{SP}^{e}$ & -1163.517761 & & & -1162.102112 & 81.7 & & & 84.3 \\
\hline $\mathrm{AlCl}+\mathrm{HCl} \leftrightarrow \mathrm{AlHCl}_{2} \mathrm{SP}^{e}$ & -1163.543944 & & & -1162.124689 & 65.2 & & & 70.1 \\
\hline $\mathrm{AlCl}_{3}$ & -1623.358956 & -1621.475524 & -1621.448747 & -1621.474935 & 0.0 & 0.0 & 0.0 & 0.0 \\
\hline $\mathrm{AlCl}_{2}+\mathrm{Cl}^{d}$ & -1623.184888 & -1621.287352 & -1621.261877 & -1621.286885 & 109.2 & 118.1 & 117.3 & 118.0 \\
\hline $\mathrm{AlCl}+\mathrm{Cl}_{2}$ & -1623.164815 & -1621.267757 & -1621.242379 & -1621.267320 & 121.8 & 130.4 & 129.5 & 130.3 \\
\hline $\mathrm{AlCl}_{2}+\mathrm{Cl} \leftrightarrow \mathrm{AlCl}+\mathrm{Cl}_{2} \mathrm{SP}^{e}$ & & & & -1621.280152 & & & & 122.2 \\
\hline $\mathrm{AlH}_{2}+\mathrm{H}_{2}$ & -244.751024 & -244.283409 & -244.285327 & -244.283153 & 0.0 & 0.0 & 0.0 & 0.0 \\
\hline $\mathrm{AlH}_{4}$ & -244.734780 & -244.262876 & -244.265198 & -244.261715 & 10.2 & 12.9 & 12.6 & 13.5 \\
\hline $\mathrm{AlH}_{3}+\mathrm{H}$ & -244.715820 & -244.250329 & -244.253945 & -244.249961 & 22.1 & 20.8 & 19.7 & 20.8 \\
\hline $\mathrm{AlH}_{2}+\mathrm{H}_{2} \leftrightarrow \mathrm{AlH}_{3}+\mathrm{H} \mathrm{SP}^{e}$ & -244.715829 & -244.247147 & -244.249302 & -244.245560 & 22.1 & 22.8 & 22.6 & 23.6 \\
\hline $\mathrm{AlH}_{2}+\mathrm{H}_{2} \leftrightarrow \mathrm{AlH}_{4} \mathrm{SP}^{e}$ & -244.736355 & -244.266541 & -244.268343 & -244.265649 & 9.2 & 10.6 & 10.7 & 11.0 \\
\hline $\mathrm{AlH}_{3}+\mathrm{H} \leftrightarrow \mathrm{AlH}_{4} \mathrm{SP}^{e}$ & & -244.254602 & -244.257584 & -244.252051 & & 18.1 & 17.4 & 19.5 \\
\hline $\mathrm{AlHCl}+\mathrm{H}_{2}$ & -704.470858 & -703.528398 & -703.519708 & -703.528080 & 0.0 & 0.0 & 0.0 & 0.0 \\
\hline $\mathrm{AlH}_{3} \mathrm{Cl}$ & -704.447696 & -703.502535 & -703.495091 & -703.500739 & 14.5 & 16.2 & 15.4 & 17.2 \\
\hline $\mathrm{AlH}_{2} \mathrm{Cl}+\mathrm{H}$ & -704.434111 & -703.494201 & -703.487800 & -703.493781 & 23.1 & 21.5 & 20.0 & 21.5 \\
\hline $\mathrm{AlH}_{2}+\mathrm{HCl}$ & -704.412739 & -703.464394 & -703.459146 & -703.464139 & 36.5 & 40.2 & 38.0 & 40.1 \\
\hline $\mathrm{AlH}_{3}+\mathrm{Cl}^{d}$ & -704.383408 & -703.434747 & -703.431916 & -703.434352 & 54.9 & 58.8 & 55.1 & 58.8 \\
\hline $\mathrm{AlH}_{2} \mathrm{Cl}+\mathrm{H} \leftrightarrow \mathrm{A}$ & -704.433770 & -703.491033 & -703.483040 & -703.489335 & 23.3 & 23.4 & 23.0 & 24.3 \\
\hline $\mathrm{AlH}_{3} \mathrm{Cl} \leftrightarrow \mathrm{AlHCl}$ & -704.446321 & -703.502294 & -703.493861 & -703.501372 & 15.4 & 16.4 & 16.2 & 16.8 \\
\hline $\mathrm{AlH}_{2}+\mathrm{HCl} \leftrightarrow \mathrm{AlH}_{2} \mathrm{Cl}+\mathrm{H} \mathrm{SP}^{e}$ & -704.413667 & -703.467889 & -703.460413 & -703.466837 & 35.9 & 38.0 & 37.2 & 38.4 \\
\hline $\mathrm{AlH}_{2} \mathrm{Cl}+\mathrm{H} \leftrightarrow \mathrm{AlH}_{3} \mathrm{Cl} \mathrm{SP}{ }^{e}$ & & -703.498512 & -703.491043 & -703.495881 & & 18.8 & 18.0 & 20.2 \\
\hline $\mathrm{AlCl}_{2}+\mathrm{H}_{2}$ & -1164.186549 & -1162.770544 & -1162.751606 & -1162.770067 & 0.0 & 0.0 & 0.0 & 0.0 \\
\hline $\mathrm{AlH}_{2} \mathrm{Cl}_{2}$ & -1164.161278 & $-1162.740694^{f}$ & $-1162.725035^{f}$ & -1162.739092 & 15.9 & $18.7^{f}$ & $16.7^{f}$ & 19.4 \\
\hline $\mathrm{AlHCl}_{2}+\mathrm{H}$ & -1164.150060 & -1162.736692 & -1162.720233 & -1162.736211 & 22.9 & 21.2 & 19.7 & 21.2 \\
\hline $\mathrm{AlHCl}+\mathrm{HCl}$ & -1164.132573 & -1162.709383 & -1162.693527 & -1162.709066 & 33.9 & 38.4 & 36.4 & 38.3 \\
\hline $\mathrm{AlH}_{2} \mathrm{Cl}+\mathrm{Cl}^{d}$ & -1164.101699 & -1162.678619 & -1162.665771 & -1162.678172 & 53.2 & 57.7 & 53.9 & 57.7 \\
\hline $\mathrm{AlH}_{2}+\mathrm{Cl}_{2}$ & -1164.004174 & -1162.576930 & -1162.561176 & -1162.576536 & 114.4 & 121.5 & 119.5 & 121.4 \\
\hline $\mathrm{AlHCl}_{2}+\mathrm{H} \leftrightarrow \mathrm{AlCl}_{2}+\mathrm{H}_{2} \mathrm{SP}^{e}$ & -1164.149246 & -1162.733438 & -1162.715378 & -1162.731684 & 23.4 & 23.3 & 22.7 & 24.1 \\
\hline $\mathrm{AlHCl}_{2}+\mathrm{H} \leftrightarrow \mathrm{AlHCl}+\mathrm{HCl} \mathrm{SP}$ & -1164.124711 & -1162.700819 & -1162.681934 & -1162.699763 & 38.8 & 43.8 & 43.7 & 44.1 \\
\hline $\mathrm{AlH}_{2} \mathrm{Cl}_{2} \leftrightarrow \mathrm{AlCl}_{2}+\mathrm{H}_{2} \mathrm{SP}^{e}$ & -1164.154273 & & & -1162.735171 & 20.3 & & & 21.9 \\
\hline $\mathrm{AlHCl}_{2}+\mathrm{H} \leftrightarrow \mathrm{AlH}_{2} \mathrm{Cl}_{2} \mathrm{SP}^{e}$ & & & & -1162.738144 & & & & 20.0 \\
\hline $\mathrm{AlCl}_{3}+\mathrm{H}$ & -1623.861112 & -1621.975342 & -1621.948747 & -1621.974753 & 0.0 & 0.0 & 0.0 & 0.0 \\
\hline $\mathrm{AlCl}_{2}+\mathrm{HCl}$ & -1623.848263 & -1621.951529 & -1621.925425 & -1621.951053 & 8.1 & 14.9 & 14.6 & 14.9 \\
\hline $\mathrm{AlHCl}_{2}+\mathrm{Cl}^{d}$ & -1623.816310 & -1621.919772 & -1621.896866 & -1621.919264 & 28.1 & 34.9 & 32.6 & 34.8 \\
\hline $\mathrm{AlHCl}+\mathrm{Cl}_{2}$ & -1623.724009 & -1621.821919 & -1621.795557 & -1621.821463 & 86.0 & 96.3 & 96.1 & 96.2 \\
\hline $\mathrm{AlCl}_{3}+\mathrm{H} \leftrightarrow \mathrm{AlCl}_{2}+\mathrm{HCl} \mathrm{SP}$ & -1623.837378 & -1621.940108 & -1621.912098 & -1621.939547 & 14.9 & 22.1 & 23.0 & 22.1 \\
\hline
\end{tabular}


TABLE 1 (Continued)

\begin{tabular}{|c|c|c|c|c|c|c|c|c|}
\hline \multirow[b]{2}{*}{ species } & \multicolumn{4}{|c|}{ total energy (hartrees) ${ }^{a}$} & \multicolumn{4}{|c|}{ relative energy $\left(\mathrm{kcal} \mathrm{mol}^{-1}\right)^{b}$} \\
\hline & $\mathrm{B} 3 \mathrm{LYP}^{c}$ & CBS-Q & G-2 & CBS-RAD & $\mathrm{B} 3 \mathrm{LYP}^{c}$ & CBS-Q & G-2 & CBS-RAD \\
\hline $\mathrm{AlHCl}_{2}+\mathrm{Cl} \leftrightarrow \mathrm{AlCl}_{2}+\mathrm{HCl} \mathrm{SP}$ & & -1621.935467 & -1621.908349 & -1621.937063 & & 25.0 & 25.4 & 23.7 \\
\hline $\mathrm{AlCl}_{4}$ & -2083.558766 & -2081.192201 & -2081.152158 & -2081.190707 & 0.0 & 0.0 & 0.0 & 0.0 \\
\hline $\mathrm{AlCl}_{3}+\mathrm{Cl}^{d}$ & -2083.528700 & -2081.159760 & -2081.126718 & -2081.159144 & 18.9 & 20.4 & 16.0 & 19.8 \\
\hline $\mathrm{AlCl}_{2}+\mathrm{Cl}_{2}$ & -2083.439699 & -2081.064065 & -2081.027455 & -2081.063450 & 74.7 & 80.4 & 78.3 & 79.9 \\
\hline
\end{tabular}

${ }^{a}$ Total energy at $0 \mathrm{~K}$, including zero-point energy. ${ }^{b}$ Energy relative to the lowest-energy configuration of the same atoms. ${ }^{c} \mathrm{~B} 3 \mathrm{LYP} / 6-$ $311+\mathrm{G}(3 \mathrm{df}, 2 \mathrm{p}) / / \mathrm{B} 3 \mathrm{~L}$ YP/6-31G(d) energy plus zero-point energy calculated from the B3LYP/6-31G(d) frequencies, scaled by $0.9804 .{ }^{d}$ Energies of $\mathrm{Al}$ and $\mathrm{Cl}$ atoms include experimental spin-orbit corrections of 0.2136 and $0.8396 \mathrm{kcal} / \mathrm{mol}$, respectively. ${ }^{e}$ SP indicates a first-order saddle point on the reaction path between the given reactant(s) and product(s). ${ }^{f}$ This structure is a first-order saddle point at the UHF/6-31G(d) level but a minimum at the UMP2/6-31G(d) level. The imaginary frequency has been ignored in computing the zero-point energy from the UHF/6-31G(d) frequencies.

TABLE 2: Geometric Parameters

\begin{tabular}{|c|c|c|c|}
\hline species & $\begin{array}{l}\text { symmetry } \\
\text { group }\end{array}$ & $\begin{array}{c}\text { figure } 1 \\
\text { part }\end{array}$ & QCISD/6-31G(d) geometric parameters ${ }^{a}(\AA$ and deg $)$ \\
\hline $\mathrm{AlH}$ & $C_{\infty v}$ & & $R(\mathrm{Al}-\mathrm{H}) 1.67$ \\
\hline $\mathrm{AlCl}$ & $C_{\infty v}$ & & $R(\mathrm{Al}-\mathrm{Cl}) 2.14$ \\
\hline $\mathrm{AlH}_{2}$ & $C_{2 v}$ & & $R(\mathrm{Al}-\mathrm{H}) 1.61, A(\mathrm{H}-\mathrm{Al}-\mathrm{H}) 118$ \\
\hline $\mathrm{AlH}_{2} \leftrightarrow \mathrm{Al}+\mathrm{H}_{2} \mathrm{SP}^{b}$ & $\mathrm{C}_{\mathrm{s}}$ & a & $R\left(\mathrm{Al}-\mathrm{H}_{1}\right) 1.80, R\left(\mathrm{Al}-\mathrm{H}_{2}\right) 1.75, A\left(\mathrm{H}_{1}-\mathrm{Al}-\mathrm{H}_{2}\right) 58$ \\
\hline $\mathrm{AlHCl}$ & $\mathrm{C}_{\mathrm{s}}$ & & $R(\mathrm{Al}-\mathrm{H}) 1.61, R(\mathrm{Al}-\mathrm{Cl}) 2.12, A(\mathrm{H}-\mathrm{Al}-\mathrm{Cl}) 116$ \\
\hline $\mathrm{Al}+\mathrm{HCl} \leftrightarrow \mathrm{AlCl}+\mathrm{H} \mathrm{SP}^{b}$ & $\mathrm{C}_{\mathrm{s}}$ & $\mathrm{b}$ & $R(\mathrm{Al}-\mathrm{Cl}) 2.37, R(\mathrm{Cl}-\mathrm{H}) 1.50, A(\mathrm{Al}-\mathrm{Cl}-\mathrm{H}) 133$ \\
\hline $\mathrm{Al}+\mathrm{HCl} \leftrightarrow \mathrm{AlHCl} \mathrm{SP}{ }^{b}$ & $\mathrm{C}_{\mathrm{s}}$ & $\mathrm{c}$ & $R(\mathrm{Al}-\mathrm{H}) 1.96, R(\mathrm{Al}-\mathrm{Cl}) 2.77, A(\mathrm{H}-\mathrm{Al}-\mathrm{Cl}) 30.6$ \\
\hline $\mathrm{Al}-\mathrm{HCl}$ cluster & $C_{\infty v}$ & $\mathrm{~d}$ & $R(\mathrm{Al}-\mathrm{H}) 3.04, R(\mathrm{H}-\mathrm{Cl}) 1.29$ \\
\hline $\mathrm{Al}-\mathrm{ClH}$ cluster & $C_{\mathrm{s}}$ & $\mathrm{e}$ & $R(\mathrm{Al}-\mathrm{Cl}) 3.74, R(\mathrm{Cl}-\mathrm{H}) 1.29, A(\mathrm{Al}-\mathrm{Cl}-\mathrm{H}) 91$ \\
\hline $\mathrm{AlCl}_{2}$ & $C_{2 v}$ & & $R(\mathrm{Al}-\mathrm{Cl}) 2.10, A(\mathrm{Cl}-\mathrm{Al}-\mathrm{Cl}) 119$ \\
\hline $\mathrm{AlH}_{3}$ & $D_{3 h}$ & & $R(\mathrm{Al}-\mathrm{H}) 1.60$ \\
\hline $\mathrm{AlH}+\mathrm{H}_{2} \leftrightarrow \mathrm{AlH}_{3} \mathrm{SP}^{b}$ & $\mathrm{C}_{\mathrm{s}}$ & $\mathrm{f}$ & $R\left(\mathrm{Al}-\mathrm{H}_{1}\right) 1.59, R\left(\mathrm{Al}-\mathrm{H}_{2}\right) 1.85, R\left(\mathrm{Al}-\mathrm{H}_{3}\right) 1.60, A\left(\mathrm{H}_{1}-\mathrm{Al}-\mathrm{H}_{2}\right) 72, A\left(\mathrm{H}_{2}-\mathrm{Al}-\mathrm{H}_{3}\right) 53$ \\
\hline $\mathrm{AlH}_{2} \mathrm{Cl}$ & $C_{2 v}$ & & $R(\mathrm{Al}-\mathrm{H}) 1.59, R(\mathrm{Al}-\mathrm{Cl}) 2.10, A(\mathrm{H}-\mathrm{Al}-\mathrm{H}) 125$ \\
\hline $\mathrm{AlH}_{2} \mathrm{Cl} \leftrightarrow \mathrm{AlCl}+\mathrm{H}_{2} \mathrm{SP}^{b}$ & $\mathrm{C}_{\mathrm{s}}$ & $\mathrm{g}$ & $R\left(\mathrm{Al}-\mathrm{H}_{1}\right) 1.59, R\left(\mathrm{Al}-\mathrm{H}_{2}\right) 1.90, R(\mathrm{Al}-\mathrm{Cl}) 2.10, A\left(\mathrm{H}_{1}-\mathrm{Al}-\mathrm{H}_{2}\right) 49, A\left(\mathrm{H}_{2}-\mathrm{Al}-\mathrm{Cl}\right) 95$ \\
\hline $\mathrm{AlH}_{2} \mathrm{Cl} \leftrightarrow \mathrm{AlH}+\mathrm{HCl} \mathrm{SP} b$ & $\mathrm{C}_{\mathrm{s}}$ & $\mathrm{h}$ & $R\left(\mathrm{Al}-\mathrm{H}_{1}\right) 1.61, R\left(\mathrm{Al}-\mathrm{H}_{2}\right) 1.75, R(\mathrm{Al}-\mathrm{Cl}) 2.59, A\left(\mathrm{H}_{2}-\mathrm{Al}-\mathrm{Cl}\right) 37, A\left(\mathrm{H}_{1}-\mathrm{Al}-\mathrm{Cl}\right) 101$ \\
\hline $\mathrm{AlHCl}+\mathrm{H} \leftrightarrow \mathrm{AlH}+\mathrm{HCl} \mathrm{SP}{ }^{b}$ & $\mathrm{C}_{\mathrm{s}}$ & $\mathrm{i}$ & $R\left(\mathrm{Al}-\mathrm{H}_{1}\right) 1.63, R(\mathrm{Al}-\mathrm{Cl}) 2.24, R\left(\mathrm{Cl}-\mathrm{H}_{2}\right) 1.67, A\left(\mathrm{H}_{1}-\mathrm{Al}-\mathrm{Cl}\right) 109, A\left(\mathrm{Al}-\mathrm{Cl}-\mathrm{H}_{2}\right) 143$ \\
\hline $\mathrm{AlHCl}_{2}$ & $C_{2 v}$ & & $R(\mathrm{Al}-\mathrm{Cl}) 2.09, R(\mathrm{Al}-\mathrm{H}) 1.58, A(\mathrm{Cl}-\mathrm{Al}-\mathrm{Cl}) 119$ \\
\hline $\mathrm{AlCl}+\mathrm{HCl} \leftrightarrow \mathrm{AlHCl}_{2} \mathrm{SP}^{b}$ & $\mathrm{C}_{\mathrm{s}}$ & $\mathrm{j}$ & $R\left(\mathrm{Al}-\mathrm{Cl}_{1}\right) 2.10, R\left(\mathrm{Al}-\mathrm{Cl}_{2}\right) 2.50, R(\mathrm{Al}-\mathrm{H}) 1.73, A\left(\mathrm{Cl}_{2}-\mathrm{Al}-\mathrm{H}\right) 41, A\left(\mathrm{Cl}_{1}-\mathrm{Al}-\mathrm{Cl}_{2}\right) 108$ \\
\hline $\mathrm{AlCl}+\mathrm{HCl} \leftrightarrow \mathrm{AlCl}_{2}+\mathrm{H} \mathrm{SP}^{b}$ & $\mathrm{C}_{\mathrm{s}}$ & $\mathrm{k}$ & $R\left(\mathrm{Al}-\mathrm{Cl}_{1}\right) 2.11, R\left(\mathrm{Al}-\mathrm{Cl}_{2}\right) 2.23, R\left(\mathrm{Cl}_{2}-\mathrm{H}\right) 1.77, A\left(\mathrm{Cl}_{1}-\mathrm{Al}-\mathrm{Cl}_{2}\right) 116, A\left(\mathrm{Al}-\mathrm{Cl}_{2}-\mathrm{H}\right) 155$. \\
\hline $\mathrm{AlCl}_{3}$ & $D_{3 h}$ & & $R(\mathrm{Al}-\mathrm{Cl}) 2.08$ \\
\hline $\mathrm{AlCl}_{2}+\mathrm{Cl} \leftrightarrow \mathrm{AlCl}+\mathrm{Cl}_{2} \mathrm{SP}^{b}$ & $\mathrm{C}_{\mathrm{s}}$ & 1 & $\begin{array}{l}R\left(\mathrm{Al}-\mathrm{Cl}_{1}\right) 2.12, R\left(\mathrm{Al}-\mathrm{Cl}_{2}\right) 2.60, R\left(\mathrm{Cl}_{2}-\mathrm{Cl}_{3}\right) 2.14, A\left(\mathrm{Cl}_{1}-\mathrm{Al}-\mathrm{Cl}_{2}\right) 125 \\
\quad A\left(\mathrm{Al}-\mathrm{Cl}_{2}-\mathrm{Cl}_{3}\right) 163\end{array}$ \\
\hline $\mathrm{AlH}_{4}$ & $C_{2 v}$ & $\mathrm{~m}$ & $R\left(\mathrm{Al}-\mathrm{H}_{1}\right) 1.59, R\left(\mathrm{Al}-\mathrm{H}_{2}\right) 1.71, A\left(\mathrm{H}_{1}-\mathrm{Al}-\mathrm{H}_{1}\right) 127, A\left(\mathrm{H}_{1}-\mathrm{Al}-\mathrm{H}_{2}\right) 114, A\left(\mathrm{H}_{2}-\mathrm{Al}-\mathrm{H}_{2}\right) 52$ \\
\hline $\mathrm{AlH}_{2}+\mathrm{H}_{2} \leftrightarrow \mathrm{AlH}_{3}+\mathrm{H} \mathrm{SP}^{b}$ & $C_{2 v}$ & $\mathrm{n}$ & $R\left(\mathrm{Al}-\mathrm{H}_{1}\right) 1.60, R\left(\mathrm{Al}-\mathrm{H}_{2}\right) 1.73, R\left(\mathrm{H}_{2}-\mathrm{H}_{3}\right) 1.20, A\left(\mathrm{H}_{1}-\mathrm{Al}-\mathrm{H}_{2}\right) 120$ \\
\hline $\mathrm{AlH}_{2}+\mathrm{H}_{2} \leftrightarrow \mathrm{AlH}_{4} \mathrm{SP}^{b}$ & $C_{2 v}$ & o & $R\left(\mathrm{Al}-\mathrm{H}_{1}\right) 1.59, R\left(\mathrm{Al}-\mathrm{H}_{2}\right) 1.71, A\left(\mathrm{H}_{1}-\mathrm{Al}-\mathrm{H}_{1}\right) 132, A\left(\mathrm{H}_{1}-\mathrm{Al}-\mathrm{H}_{2}\right) 112, A\left(\mathrm{H}_{2}-\mathrm{Al}-\mathrm{H}_{2}\right) 41$ \\
\hline $\mathrm{AlH}_{3}+\mathrm{H} \leftrightarrow \mathrm{AlH}_{4} \mathrm{SP}^{b}$ & $\mathrm{C}_{\mathrm{s}}$ & $\mathrm{p}$ & $R\left(\mathrm{Al}-\mathrm{H}_{1}\right) 1.50, R\left(\mathrm{Al}-\mathrm{H}_{2}\right) 1.62, R\left(\mathrm{Al}-\mathrm{H}_{3}\right) 2.11, A\left(\mathrm{H}_{1}-\mathrm{Al}-\mathrm{H}_{2}\right) 119, A\left(\mathrm{H}_{2}-\mathrm{Al}-\mathrm{H}_{3}\right) 68$ \\
\hline $\mathrm{AlH}_{3} \mathrm{Cl}$ & $\mathrm{C}_{\mathrm{s}}$ & $\mathrm{q}$ & $\begin{array}{l}R\left(\mathrm{Al}-\mathrm{H}_{1}\right) 1.71, R\left(\mathrm{Al}-\mathrm{H}_{2}\right) 1.58, R(\mathrm{Al}-\mathrm{Cl}) 2.10, A\left(\mathrm{H}_{1}-\mathrm{Al}-\mathrm{H}_{1}\right) 58, A\left(\mathrm{H}_{1}-\mathrm{Al}-\mathrm{H}_{2}\right) 118 \\
\quad A\left(\mathrm{H}_{1}-\mathrm{Al}-\mathrm{Cl}\right) 113\end{array}$ \\
\hline $\mathrm{AlH}_{2} \mathrm{Cl}+\mathrm{H} \leftrightarrow \mathrm{AlHCl}+\mathrm{H}_{2} \mathrm{SP}^{b}$ & $\mathrm{C}_{\mathrm{s}}$ & $\mathrm{r}$ & $\begin{array}{l}R\left(\mathrm{Al}-\mathrm{H}_{1}\right) 1.59, R(\mathrm{Al}-\mathrm{Cl}) 2.11, R\left(\mathrm{Al}-\mathrm{H}_{2}\right) 1.71, R\left(\mathrm{H}_{2}-\mathrm{H}_{3}\right) 1.21, A\left(\mathrm{H}_{1}-\mathrm{Al}-\mathrm{Cl}\right) 117 \\
\quad A\left(\mathrm{H}_{1}-\mathrm{Al}-\mathrm{H}_{2}\right) 125, A\left(\mathrm{Al}-\mathrm{H}_{2}-\mathrm{H}_{3}\right) 179\end{array}$ \\
\hline $\mathrm{AlH}_{2}+\mathrm{HCl} \leftrightarrow \mathrm{AlH}_{2} \mathrm{Cl}+\mathrm{H} \mathrm{SP}^{b}$ & $\mathrm{C}_{\mathrm{s}}$ & $\mathrm{s}$ & $\begin{array}{l}R\left(\mathrm{Al}-\mathrm{H}_{1}\right) 1.59, R\left(\mathrm{Al}-\mathrm{H}_{2}\right) 1.97, R\left(\mathrm{H}_{2}-\mathrm{Cl}\right) 1.41, A\left(\mathrm{H}_{1}-\mathrm{Al}-\mathrm{H}_{1}\right), 126, A\left(\mathrm{H}_{1}-\mathrm{Al}-\mathrm{H}_{2}\right) 114 \\
\quad A\left(\mathrm{Al}-\mathrm{H}_{2}-\mathrm{Cl}_{5}\right) 97\end{array}$ \\
\hline $\mathrm{AlH}_{3} \mathrm{Cl} \leftrightarrow \mathrm{AlHCl}+\mathrm{H}_{2} \mathrm{SP}^{b}$ & $C_{1}$ & $\mathrm{t}$ & $\begin{array}{l}R\left(\mathrm{Al}-\mathrm{H}_{1}\right) 1.58, R(\mathrm{Al}-\mathrm{Cl}) 2.10, R\left(\mathrm{Al}-\mathrm{H}_{2}\right) 1.67, R\left(\mathrm{Al}-\mathrm{H}_{3}\right) 1.77, A\left(\mathrm{H}_{1}-\mathrm{Al}-\mathrm{Cl}\right) 128 \\
\quad A\left(\mathrm{H}_{1}-\mathrm{Al}-\mathrm{H}_{2}\right) 118, A\left(\mathrm{H}_{1}-\mathrm{Al}-\mathrm{H}_{3}\right) 109, A\left(\mathrm{H}_{2}-\mathrm{Al}-\mathrm{H}_{3}\right) 35, A\left(\mathrm{H}_{2}-\mathrm{Al}-\mathrm{Cl}\right) 110\end{array}$ \\
\hline $\mathrm{AlH}_{2} \mathrm{Cl}+\mathrm{H} \leftrightarrow \mathrm{AlH}_{3} \mathrm{Cl} \mathrm{SP}{ }^{b}$ & $C_{1}$ & $\mathrm{u}$ & $\begin{array}{l}R\left(\mathrm{Al}-\mathrm{H}_{1}\right) 1.61, R\left(\mathrm{Al}-\mathrm{H}_{2}\right) 1.59, R\left(\mathrm{Al}-\mathrm{H}_{3}\right) 2.01, R(\mathrm{Al}-\mathrm{Cl}) 2.11, A\left(\mathrm{H}_{1}-\mathrm{Al}-\mathrm{H}_{2}\right) 124, \\
\quad A\left(\mathrm{H}_{1}-\mathrm{Al}-\mathrm{H}_{3}\right) 68, A\left(\mathrm{H}_{1}-\mathrm{Al}-\mathrm{Cl}\right) 117, R\left(\mathrm{H}_{2}-\mathrm{Al}-\mathrm{H}_{3}\right) 106, R\left(\mathrm{H}_{2}-\mathrm{Al}-\mathrm{Cl}\right) 119\end{array}$ \\
\hline $\mathrm{AlH}_{2} \mathrm{Cl}_{2}$ & $C_{2 v}$ & $\mathrm{v}$ & $R(\mathrm{Al}-\mathrm{H}) 1.70, R(\mathrm{Al}-\mathrm{Cl}) 2.09, A(\mathrm{H}-\mathrm{Al}-\mathrm{H}) 63, A(\mathrm{H}-\mathrm{Al}-\mathrm{Cl}) 115$ \\
\hline $\mathrm{AlHCl}_{2}+\mathrm{H} \leftrightarrow \mathrm{AlCl}_{2}+\mathrm{H}_{2} \mathrm{SP}^{b}$ & $C_{2 v}$ & $\mathrm{w}$ & $R(\mathrm{Al}-\mathrm{Cl}) 2.09, R\left(\mathrm{Al}-\mathrm{H}_{1}\right) 1.69, R\left(\mathrm{H}_{1}-\mathrm{H}_{2}\right) 1.22, A\left(\mathrm{Cl}-\mathrm{Al}-\mathrm{H}_{1}\right) 121$ \\
\hline $\begin{array}{l}\mathrm{AlHCl}_{2}+\mathrm{H} \leftrightarrow \mathrm{AlHCl}+ \\
\quad \mathrm{HCl} \mathrm{SP} b\end{array}$ & $C_{1}$ & $\mathrm{x}$ & $\begin{array}{l}R\left(\mathrm{Al}-\mathrm{H}_{1}\right) 1.59, R\left(\mathrm{Al}-\mathrm{Cl}_{1}\right) 2.11, R\left(\mathrm{Al}-\mathrm{Cl}_{2}\right) 2.26, R\left(\mathrm{Cl}_{2}-\mathrm{H}_{2}\right) 1.52, A\left(\mathrm{H}_{1}-\mathrm{Al}-\mathrm{Cl}_{1}\right) 120 \\
\quad A\left(\mathrm{H}_{1}-\mathrm{Al}-\mathrm{Cl}_{2}\right) 115, A\left(\mathrm{Cl}_{1}-\mathrm{Al}-\mathrm{Cl}_{2}\right) 114, A\left(\mathrm{Al}-\mathrm{Cl}_{2}-\mathrm{H}_{2}\right) 135, D\left(\mathrm{H}_{1}-\mathrm{Al}-\mathrm{Cl}_{2}-\mathrm{H}_{2}\right) 67\end{array}$ \\
\hline $\mathrm{AlH}_{2} \mathrm{Cl}_{2} \leftrightarrow \mathrm{AlCl}_{2}+\mathrm{H}_{2} \mathrm{SP}^{b}$ & $\mathrm{C}_{\mathrm{s}}$ & $\mathrm{y}$ & $\begin{array}{l}R(\mathrm{Al}-\mathrm{Cl}) 2.09, R\left(\mathrm{Al}-\mathrm{H}_{1}\right) 1.64, R\left(\mathrm{Al}-\mathrm{H}_{2}\right) 1.86, A\left(\mathrm{Cl}-\mathrm{Al}-\mathrm{H}_{1}\right) 117, A\left(\mathrm{Cl}-\mathrm{Al}-\mathrm{H}_{2}\right) 108 \\
\quad A\left(\mathrm{H}_{1}-\mathrm{Al}-\mathrm{H}_{2}\right) 36\end{array}$ \\
\hline $\mathrm{AlHCl}_{2}+\mathrm{H} \leftrightarrow \mathrm{AlH}_{2} \mathrm{Cl}_{2} \mathrm{SP}^{b}$ & $\mathrm{C}_{\mathrm{s}}$ & $\mathrm{z}$ & $\begin{array}{l}R(\mathrm{Al}-\mathrm{Cl}) 2.09, R\left(\mathrm{Al}-\mathrm{H}_{1}\right) 1.61, R\left(\mathrm{Al}-\mathrm{H}_{2}\right) 1.92, A\left(\mathrm{Cl}-\mathrm{Al}-\mathrm{H}_{1}\right) 119, A\left(\mathrm{Cl}-\mathrm{Al}-\mathrm{H}_{2}\right) 106 \\
\quad A\left(\mathrm{H}_{1}-\mathrm{Al}-\mathrm{H}_{2}\right) 70\end{array}$ \\
\hline $\mathrm{AlCl}_{3}+\mathrm{H} \leftrightarrow \mathrm{AlCl}_{2}+\mathrm{HCl} \mathrm{SP}$ & $\mathrm{C}_{\mathrm{s}}$ & $a^{\prime}$ & $\begin{array}{l}R\left(\mathrm{Al}-\mathrm{Cl}_{1}\right) 2.10, R\left(\mathrm{Al}-\mathrm{Cl}_{2}\right) 2.26, R\left(\mathrm{Cl}_{2}-\mathrm{H}\right) 1.54, A\left(\mathrm{Cl}_{1}-\mathrm{Al}-\mathrm{Cl}_{1}\right) 119 \\
\quad A\left(\mathrm{Cl}_{1}-\mathrm{Al}-\mathrm{Cl}_{2}\right) 115, A\left(\mathrm{Al}-\mathrm{Cl}_{2}-\mathrm{H}\right) 139\end{array}$ \\
\hline $\mathrm{AlHCl}_{2}+\mathrm{Cl} \leftrightarrow \mathrm{AlCl}_{2}+\mathrm{HCl} \mathrm{SP}{ }^{b}$ & $C_{2 v}$ & $b^{\prime}$ & $R\left(\mathrm{Al}-\mathrm{Cl}_{1}\right) 2.08, R(\mathrm{Al}-\mathrm{H}) 1.68, R\left(\mathrm{H}-\mathrm{Cl}_{2}\right) 1.71, A\left(\mathrm{Cl}_{1}-\mathrm{Al}-\mathrm{H}\right) 119$ \\
\hline $\mathrm{AlCl}_{4}$ & $C_{2 v}$ & $\mathrm{c}^{\prime}$ & $R\left(\mathrm{Al}-\mathrm{Cl}_{1}\right) 2.09, R\left(\mathrm{Al}-\mathrm{Cl}_{2}\right) 2.23, A\left(\mathrm{Cl}_{1}-\mathrm{Al}-\mathrm{Cl}_{1}\right) 120, A\left(\mathrm{Cl}_{1}-\mathrm{Al}-\mathrm{Cl}_{2}\right) 113$ \\
\hline $\mathrm{H}_{2}$ & $D_{\infty h}$ & & $R(\mathrm{H}-\mathrm{H}) 0.75$ \\
\hline $\mathrm{HCl}$ & $C_{\infty v}$ & & $R(\mathrm{H}-\mathrm{Cl}) 1.29$ \\
\hline $\mathrm{Cl}_{2}$ & $D_{\infty h}$ & & $R(\mathrm{Cl}-\mathrm{Cl}) 2.03$ \\
\hline
\end{tabular}

${ }^{a} R(\mathrm{~A}-\mathrm{B})$ indicates the distance between atoms $\mathrm{A}$ and $\mathrm{B}, A(\mathrm{~A}-\mathrm{B}-\mathrm{C})$ indicates the $\mathrm{A}-\mathrm{B}-\mathrm{C}$ bond angle, and $D(\mathrm{~A}-\mathrm{B}-\mathrm{C}-\mathrm{D})$ indicates a the dihedral angle between $\mathrm{A}$ and $\mathrm{D}$ about the $\mathrm{B}-\mathrm{C}$ bond. ${ }^{b} \mathrm{SP}$ indicates a first-order saddle point on the reaction path between the given reactant(s) and product(s). 
unpaired electrons). All of the above methods use spinunrestricted wave functions for open-shell species. These are not necessarily eigenfunctions of the spin-squared operator $\left(S^{2}\right)$ and, therefore, do not yield pure doublet, triplet, etc. states. They may be contaminated by the states of higher-spin multiplicity. This spin contamination leads to values of $\left\langle S^{2}\right\rangle$ that are greater than those of the pure spin states (i.e., $\left\langle S^{2}\right\rangle$ greater than 0.75 for doublets, greater than 2.0 for triplets, etc.). For species with mild spin contamination $\left(\left\langle S^{2}\right\rangle\right.$ within 0.05 or so of the value for the pure spin state), the above methods were found by Mayer et al. ${ }^{16}$ to perform well. However, for more severely spincontaminated wave functions, they do not give reliable energies. The effect of spin contamination on computed energies is discussed in more detail by Mayer et al. ${ }^{16}$ In addition, for some of the transition states studied here that are nominally closedshell species, the restricted Hartree-Fock wave function was found to be unstable with respect to becoming unrestricted. In other cases, no transition state was found at the restricted Hartree-Fock level, or one was found that was qualitatively different from those found at higher levels or at the unrestricted Hartree-Fock level. In these cases, the CBS-Q and G-2 methods could not be used, since they are based on restricted HartreeFock methods for closed-shell species. Of course, the restricted calculations could be replaced with their unrestricted counterparts, but then it is questionable whether the result can still be called a CBS-Q or G-2 calculation. Therefore, the CBS-RAD method, recommended by Mayer et al. ${ }^{16}$ for computing highaccuracy energies of free radicals, was also applied to all of the molecules and transition states considered here. This is a variant of the CBS-Q method, in which the geometry optimization and frequency calculation are done at the QCISD/6-31G(d) level of theory, and the larger QCISD energy calculation is replaced by a coupled-cluster $(\mathrm{CCSD}(\mathrm{T}))$ calculation. This procedure was shown by Mayer et al. ${ }^{16}$ to give more accurate energies than the G-2 or CBS-Q methods for spin-contaminated radical species. In the CBS-RAD method, we used unrestricted wave functions for all species, including nominally closed-shell species. In most cases, for the closed-shell species, pure singlet states were obtained $\left(\left\langle S^{2}\right\rangle=0\right)$, but for several of the transition states whose wave functions had RHF to UHF instabilities, somewhat spin-contaminated wave functions were obtained. In general, the CBS-RAD results were consistent with the CBS-Q and G-2 results. Chuang et al. ${ }^{17}$ studied the ability of singlereference methods to predict the properties of open-shell transition states and found that unrestricted quadradic configuration interaction (UQCISD) performed much better than unrestricted second-order Møller-Plesset perturbation theory (UMP2) in predicting transition state geometries and that it performed nearly as well as coupled-cluster methods (UCCSD and variants on it). We therefore expect that the UQCISD/6-31G(d) geometry optimizations and frequency calculations performed as part of the CBS-RAD method will provide more reliable geometries and frequencies than the other methods used here.

\section{Results and Discussion}

Computed energies of reactants, products, and transition states for possible reactions in the $\mathrm{Al}-\mathrm{H}-\mathrm{Cl}$ system are given in Table 1. Blank entries in the table indicate that a particular method was not applicable to a particular structure. The reasons for this are given below. We have previously reported heats of formation computed from these results for many of the stable species, ${ }^{6}$ but none of the transition state properties have been previously presented. Allendorf and co-workers ${ }^{18,19}$ have previously presented heats of formation of several of these species based on G-2 calculations. Table 2 presents the bond lengths and angles needed to specify the geometry of each species. Selected molecules and transition states are illustrated in Figure 1. Table 3 presents the computed vibrational frequencies and moments of inertia for each of the species included in Table 1. The QCISD/6-31G(d) frequencies have been scaled by 0.9537 , as recommended by Scott and Radom. ${ }^{20}$ Note that a different scaling factor (0.9776) was used for the zero-point energy, also as recommended by Scott and Radom. ${ }^{20}$ The numbers given in Table 1 are illustrated in schematic energy diagrams in Figure 2. This figure also shows the many reaction paths that have no energetic barrier and for which, therefore, no transition state properties are given in Table 1. Possible reactions for each stoichiometry- $\mathrm{AlH}_{x} \mathrm{Cl}_{2-x}(x=0-2), \mathrm{AlH}_{x} \mathrm{Cl}_{3-x}(x=0-3)$, and $\mathrm{AlH}_{x} \mathrm{Cl}_{4-x}(x=0-4)$ - are discussed individually below. In the tables and in Figure 1, we have included information on structures that are first-order saddle points at some levels of theory even when at the highest levels of theory used these structures become significantly lower in energy than the reactants and would therefore, in the context of variational transition state theory, not be transition states.

In this study, we have considered only reactions involving a single aluminum atom and five or fewer total atoms. We have not considered processes involving dimers of $\mathrm{AlH}_{x} \mathrm{Cl}_{3-x}$ that are known to exist in the gas phase at moderate temperatures, nor have we considered processes involving complexes such as $\mathrm{AlCl}_{3} \cdot \mathrm{HCl}$. The binding energy of the $\mathrm{AlCl}_{3} \cdot \mathrm{HCl}$ complex was computed by Senger and Radom ${ }^{21}$ to be about $8 \mathrm{kcal} / \mathrm{mol}$. The binding energy for the $\mathrm{AlCl}_{3}$ dimer is about $30 \mathrm{kcal} / \mathrm{mol}{ }^{22}$ Thus, a complete model of reactions in the $\mathrm{Al}-\mathrm{H}-\mathrm{Cl}$ system would need to include such processes to be applicable at temperatures below about $1000 \mathrm{~K}$, where such complex formation can be significant. If the only possible reactions are reversible complex formations, then this will not add much to the chemistry. However, if the complexes can rearrange and decompose to a pair of compounds other than that from which they formed, processes proceeding through such complexes may be important. In any case, the investigation of such complexes and their reactions goes beyond the scope of the present study.

$\mathbf{A l H}_{2}$. The potential surface for $\mathrm{AlH}_{2}$ is shown schematically in Figure 2a. Decomposition of $\mathrm{AlH}_{2}$ to $\mathrm{AlH}+\mathrm{H}$ is a simple bond-breaking reaction that is barrierless in the reverse direction. Decomposition of $\mathrm{AlH}_{2}$ to $\mathrm{Al}+\mathrm{H}_{2}$ is thermodynamically preferable to decomposition to $\mathrm{AlH}+\mathrm{H}$ but has approximately the same energetic barrier to reaction. Since decomposition to $\mathrm{Al}+\mathrm{H}_{2}$ will proceed through a tight transition state while decomposition to $\mathrm{AlH}+\mathrm{H}$ proceeds through a loose transition state, decomposition to $\mathrm{AlH}+\mathrm{H}$ can be expected to be faster. The transition state for the decomposition of $\mathrm{AlH}_{2}$ to $\mathrm{Al}+\mathrm{H}_{2}$ could not be located at the HF/6-31G(d) level, and therefore, no CBS-Q or G-2 results are presented for this structure. There is no energetic barrier for direct $\mathrm{H}$ abstraction from $\mathrm{AlH}$ by $\mathrm{H}$. This was confirmed by conducting scans of the potential surface at the HF/6-31G(d) and B3LYP/6-31G(d) levels and identifying a barrierless path from $\mathrm{AlH}+\mathrm{H}$ to $\mathrm{Al}+\mathrm{H}_{2}$.

AlHCl. The potential surface for $\mathrm{AlHCl}$ is shown schematically in Figure $2 \mathrm{~b}$. The $\mathrm{Al}+\mathrm{HCl}$ reaction has been studied both experimentally and theoretically. In high-temperature fastflow reactor studies, Rogowski et al. ${ }^{2}$ measured a rate constant of $1.5 \times 10^{-10} \exp (-800 / T) \mathrm{cm}^{3}$ molecule ${ }^{-1} \mathrm{~s}^{-1}$. Both Sakai ${ }^{4}$ and Fängström et al. ${ }^{5}$ have studied this reaction using ab initio methods. Sakai considered only the insertion reaction to give $\mathrm{AlHCl}$, while Fängström et al. also considered the $\mathrm{Cl}$ atom transfer to give $\mathrm{AlCl}+\mathrm{H}$. These two studies agree with the present result that $\mathrm{Al}$ and $\mathrm{HCl}$ can form two weakly bound 
(a)

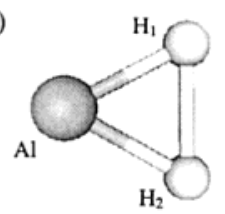

(e)

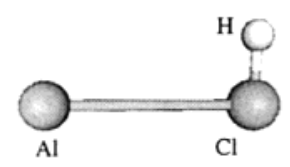

(i)

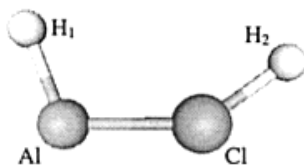

(m)

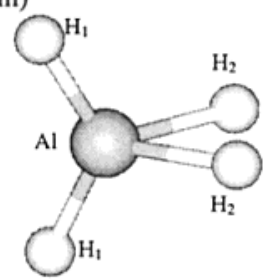

(q)

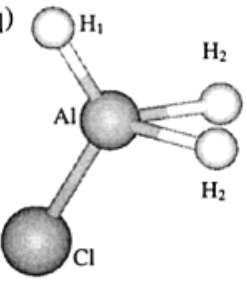

(u)

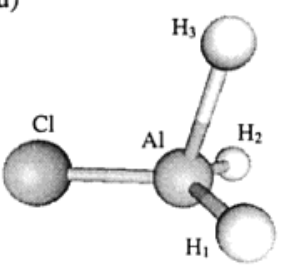

(y)

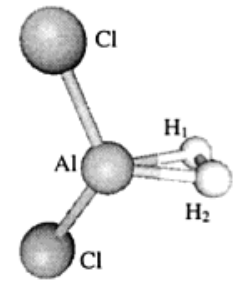

(c')

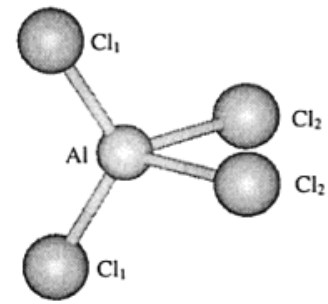

(b)

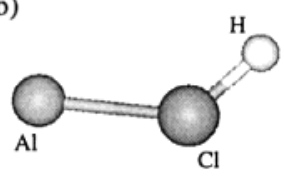

(f)

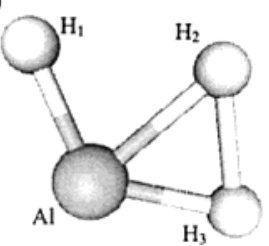

(j)

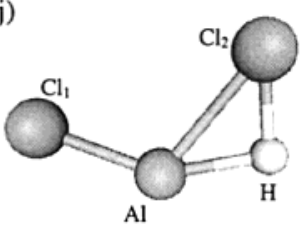

(n)

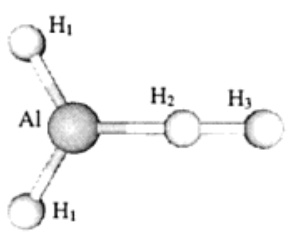

(r)

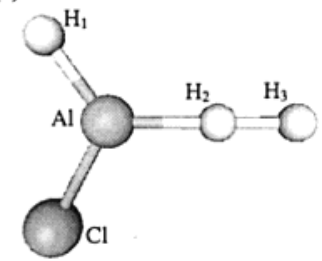

(v)

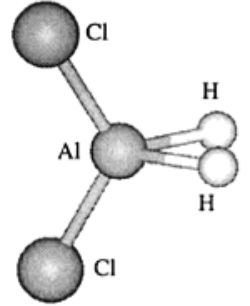

(z)

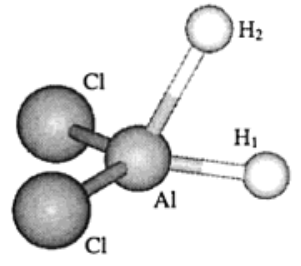

(o)

(w) (c)

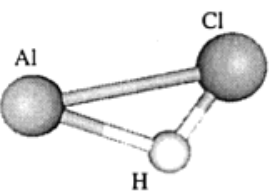

(g)

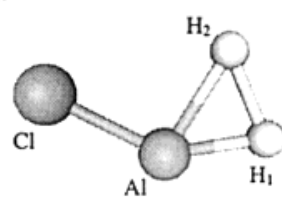

(k)
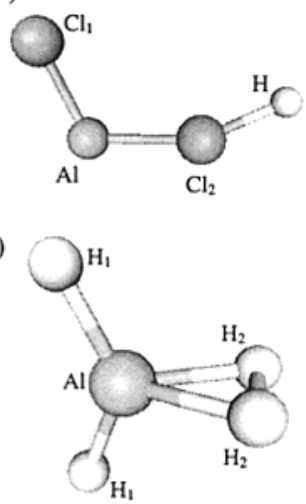

(s)
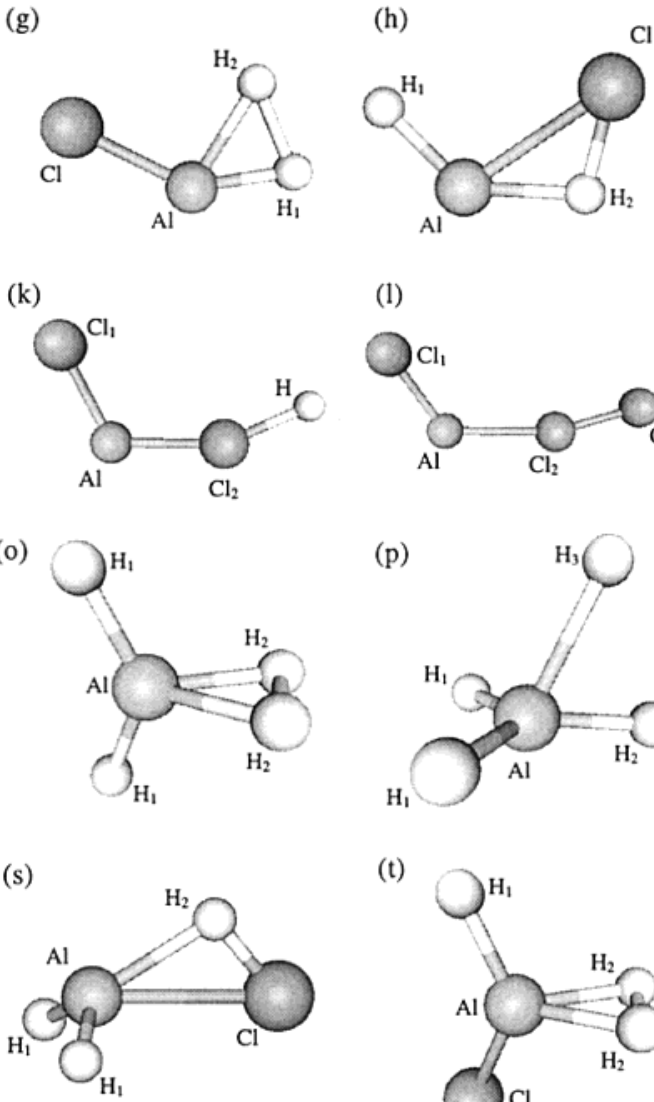

(l)<smiles>O=C(Cl)OC=C(Cl)Cl</smiles>

(p)

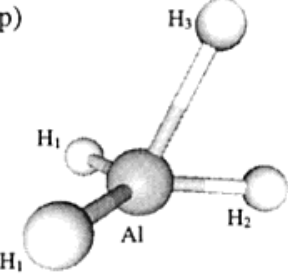

(t)
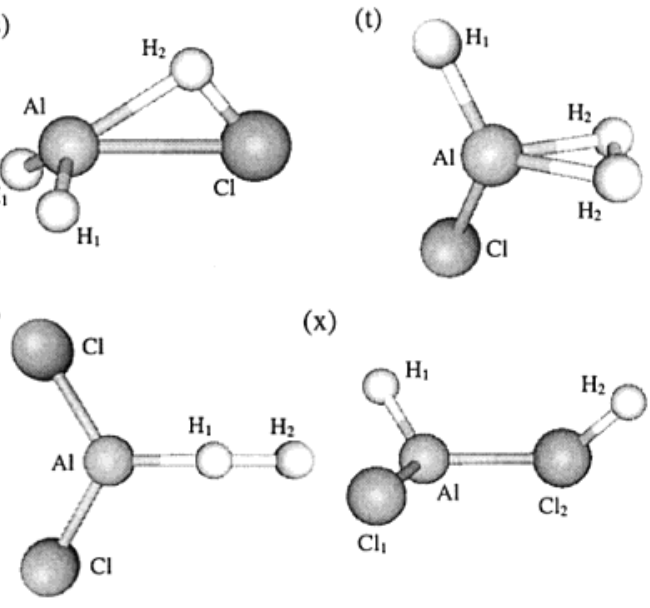

(a')

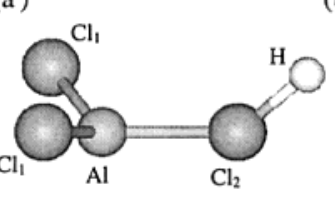

b')

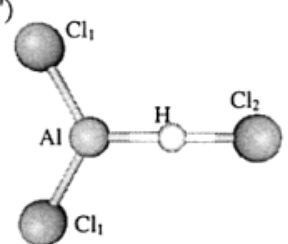

Figure 1. Structures of the selected molecules (potential energy surface minima) and first-order saddle points investigated here.

addition complexes, a linear $\mathrm{Al}-\mathrm{HCl}$ structure, and a bent $\mathrm{Al}-$ $\mathrm{ClH}$ structure. As found by Fängström et al., the bent $\mathrm{Al}-\mathrm{ClH}$ cluster is not present at the B3LYP/6-31G(d) level. The transition state leading to $\mathrm{AlHCl}$ is slightly higher in energy than the addition complexes if only electronic energy is considered. However, inclusion of zero-point energy and 
TABLE 3: Vibrational Frequencies and Moments of Inertia ${ }^{a}$

\begin{tabular}{|c|c|c|c|c|c|c|c|c|c|c|c|c|}
\hline species & \multicolumn{9}{|c|}{ scaled QCISD/6-31G(d) vibrational frequencies $\left(\mathrm{cm}^{-1}\right)$} & \multicolumn{3}{|c|}{$\begin{array}{c}\text { moments of } \\
\text { inertia }\left(\text { amu } \AA^{2}\right)\end{array}$} \\
\hline $\mathrm{AlH}$ & 1596 & & & & & & & & & 2.7 & & \\
\hline $\mathrm{AlCl}$ & 473 & & & & & & & & & 69.8 & & \\
\hline $\mathrm{AlH}_{2}$ & 729 & 1750 & 1790 & & & & & & & 1.3 & 3.9 & 5.1 \\
\hline $\mathrm{AlH}_{2} \leftrightarrow \mathrm{Al}+\mathrm{H}_{2} \mathrm{SP}^{b}$ & -4003 & 758 & 1346 & & & & & & & 1.5 & 4.5 & 6.0 \\
\hline $\mathrm{AlHCl}$ & 495 & 552 & 1734 & & & & & & & 2.0 & 71.9 & 73.9 \\
\hline $\mathrm{Al}+\mathrm{HCl} \leftrightarrow \mathrm{AlCl}+\mathrm{H} \mathrm{SP}^{b}$ & -2836 & 285 & 470 & & & & & & & 1.2 & 89.4 & 90.5 \\
\hline $\mathrm{Al}+\mathrm{HCl} \leftrightarrow \mathrm{AlHCl} \mathrm{SP}{ }^{b}$ & -946 & 200 & 1063 & & & & & & & 1.0 & 117 & 118 \\
\hline $\mathrm{Al}-\mathrm{HCl}$ cluster & 61 & 201 & 201 & 2699 & & & & & & 287 & & \\
\hline $\mathrm{Al}-\mathrm{ClH}$ cluster & 42 & 107 & 2843 & & & & & & & 1.6 & 215 & 217 \\
\hline $\mathrm{AlCl}_{2}$ & 148 & 451 & 567 & & & & & & & 22.3 & 230 & 252 \\
\hline $\mathrm{AlH}_{3}$ & 671 & 751 & 751 & 1834 & 1850 & 1850 & & & & 3.9 & 3.9 & 7.7 \\
\hline $\mathrm{AlH}+\mathrm{H}_{2} \leftrightarrow \mathrm{AlH}_{3} \mathrm{SP}^{b}$ & -917 & 309 & 678 & 1025 & 1808 & 1858 & & & & 3.6 & 4.7 & 8.2 \\
\hline $\mathrm{AlH}_{2} \mathrm{Cl}$ & 500 & 514 & 577 & 747 & 1871 & 1891 & & & & 4.0 & 74.6 & 78.6 \\
\hline $\mathrm{AlH}_{2} \mathrm{Cl} \leftrightarrow \mathrm{AlCl}+\mathrm{H}_{2} \mathrm{SP}^{b}$ & -1191 & 390 & 450 & 516 & 960 & 1837 & & & & 4.0 & 75.6 & 79.6 \\
\hline $\mathrm{AlH}_{2} \mathrm{Cl} \leftrightarrow \mathrm{AlH}+\mathrm{HCl} \mathrm{SP}$ & -1296 & 228 & 460 & 493 & 1341 & 1780 & & & & 3.6 & 105 & 109 \\
\hline $\mathrm{AlHCl}+\mathrm{H} \leftrightarrow \mathrm{AlH}+\mathrm{HCl} \mathrm{SP}{ }^{b}$ & -1542 & 308 & 369 & 466 & 557 & 1724 & & & & 3.3 & 84.9 & 88.2 \\
\hline $\mathrm{AlHCl}_{2}$ & 161 & 433 & 470 & 573 & 646 & 1924 & & & & 27.7 & 225 & 253 \\
\hline $\mathrm{AlCl}+\mathrm{HCl} \leftrightarrow \mathrm{AlHCl}_{2} \mathrm{SP}^{b}$ & -1415 & 102 & 290 & 308 & 514 & 1385 & & & & 35.9 & 248 & 284 \\
\hline $\mathrm{AlCl}+\mathrm{HCl} \leftrightarrow \mathrm{AlCl}_{2}+\mathrm{H} \mathrm{SP}^{b}$ & -1275 & 113 & 285 & 309 & 429 & 524 & & & & 29.0 & 245 & 274 \\
\hline $\mathrm{AlCl}_{3}$ & 146 & 146 & 198 & 376 & 612 & 612 & & & & 226 & 226 & 452 \\
\hline $\mathrm{AlCl}_{2}+\mathrm{Cl} \leftrightarrow \mathrm{AlCl}+\mathrm{Cl}_{2} \mathrm{SP}^{b}$ & -463 & 26 & 118 & 133 & 235 & 497 & & & & 51 & 723 & 774 \\
\hline $\mathrm{AlH}_{4}$ & 470 & 566 & 568 & 626 & 778 & 1223 & 1433 & 1858 & 1877 & 5.2 & 6.9 & 9.8 \\
\hline $\mathrm{AlH}_{2}+\mathrm{H}_{2} \leftrightarrow \mathrm{AlH}_{3}+\mathrm{H} \mathrm{SP}^{b}$ & -1503 & 247 & 268 & 739 & 772 & 853 & 941 & 1816 & 1836 & 3.9 & 12.6 & 16.5 \\
\hline $\mathrm{AlH}_{2}+\mathrm{H}_{2} \leftrightarrow \mathrm{AlH}_{4} \mathrm{SP}^{b}$ & -720 & 407 & 612 & 726 & 727 & 1378 & 1455 & 1869 & 1895 & 5.0 & 6.6 & 10.1 \\
\hline $\mathrm{AlH}_{3}+\mathrm{H} \leftrightarrow \mathrm{AlH}_{4} \mathrm{SP}^{b}$ & -438 & 272 & 444 & 665 & 725 & 741 & 1762 & 1844 & 1855 & 6.4 & 8.2 & 9.7 \\
\hline $\mathrm{AlH}_{3} \mathrm{Cl}$ & 330 & 414 & 494 & 512 & 640 & 773 & 1138 & 1445 & 1896 & 6.8 & 79.3 & 83.3 \\
\hline $\mathrm{AlH}_{2} \mathrm{Cl}+\mathrm{H} \leftrightarrow \mathrm{AlHCl}+\mathrm{H}_{2} \mathrm{SP}^{b}$ & -1516 & 155 & 246 & 509 & 558 & 732 & 839 & 971 & 1848 & 10.2 & 81.9 & 92.1 \\
\hline $\mathrm{AlH}_{2}+\mathrm{HCl} \leftrightarrow \mathrm{AlH}_{2} \mathrm{Cl}+\mathrm{H} \mathrm{SP}^{b}$ & -784 & 198 & 362 & 464 & 598 & 692 & 1450 & 1827 & 1862 & 5.9 & 109 & 111 \\
\hline $\mathrm{AlH}{ }_{3} \mathrm{Cl} \leftrightarrow \mathrm{AlHCl}+\mathrm{H}_{2} \mathrm{SP}^{b}$ & -1033 & 368 & 436 & 522 & 653 & 789 & 1236 & 1620 & 1915 & 6.5 & 79.0 & 84.1 \\
\hline $\mathrm{AlH}_{2} \mathrm{Cl}+\mathrm{H} \leftrightarrow \mathrm{AlH}_{3} \mathrm{Cl} \mathrm{SP}{ }^{b}$ & -410 & 256 & 487 & 509 & 12 & 603 & 719 & 1757 & 1885 & 7.7 & 80.1 & 83.0 \\
\hline $\mathrm{AlH}_{2} \mathrm{Cl}_{2}$ & 156 & 187 & 441 & 460 & 474 & 604 & 722 & 1081 & 1469 & 32.0 & 232 & 261 \\
\hline $\mathrm{AlHCl}_{2}+\mathrm{H} \leftrightarrow \mathrm{AlCl}_{2}+\mathrm{H}_{2} \mathrm{SP}^{b}$ & -1512 & 152 & 153 & 156 & 458 & 581 & 683 & 799 & 1012 & 41.5 & 227 & 268 \\
\hline $\mathrm{AlHCl}_{2}+\mathrm{H} \leftrightarrow \mathrm{AlHCl}+\mathrm{HCl} \mathrm{SP}$ & -1628 & 109 & 283 & 302 & 471 & 520 & 588 & 599 & 1857 & 35.3 & 244 & 276 \\
\hline $\mathrm{AlH}_{2} \mathrm{Cl}_{2} \leftrightarrow \mathrm{AlCl}_{2}+\mathrm{H}_{2} \mathrm{SP}^{b}$ & -1408 & 148 & 369 & 383 & 455 & 604 & 742 & 873 & 1730 & 30.2 & 238 & 265 \\
\hline $\mathrm{AlHCl}_{2}+\mathrm{H} \leftrightarrow \mathrm{AlH}_{2} \mathrm{Cl}_{2} \mathrm{SP}^{b}$ & -277 & 157 & 293 & 459 & 505 & 551 & 589 & 614 & 1742 & 33.0 & 231 & 259 \\
\hline $\mathrm{AlCl}_{3}+\mathrm{H} \leftrightarrow \mathrm{AlCl}_{2}+\mathrm{HCl} \mathrm{SP}{ }^{b}$ & -1485 & 92 & 120 & 169 & 294 & 362 & 429 & 540 & 584 & 233 & 255 & 478 \\
\hline $\mathrm{AlHCl}_{2}+\mathrm{H} \leftrightarrow \mathrm{AlCl}_{2}+\mathrm{HCl} \mathrm{SP}$ & -400 & 36 & 60 & 142 & 378 & 433 & 583 & 584 & 633 & 232 & 457 & 688 \\
\hline $\mathrm{AlCl}_{4}$ & 90 & 131 & 144 & 149 & 213 & 243 & 344 & 530 & 599 & 356 & 409 & 508 \\
\hline $\mathrm{H}_{2}$ & 4140 & & & & & & & & & 0.28 & & \\
\hline $\mathrm{HCl}$ & 2845 & & & & & & & & & 1.6 & & \\
\hline $\mathrm{Cl}_{2}$ & 499 & & & & & & & & & 72.0 & & \\
\hline
\end{tabular}

${ }^{a}$ Vibrational frequencies computed at the QCISD/6-31G(d) level have been scaled by 0.9537 , as recommended by Scott and Radom. ${ }^{20}{ }^{b}$ SP indicates a first-order saddle point on the reaction path between the given reactant(s) and product(s).

calculation of the electronic energy at higher levels shifts this saddle point to an energy slightly lower than that of the addition complexes. Thus, there is no true energetic barrier to this reaction. This reaction should also be pressure-dependent, and in the low-pressure limit, chemically activated $\mathrm{AlHCl}$ produced from $\mathrm{Al}+\mathrm{HCl}$ will decompose to $\mathrm{AlCl}+\mathrm{H}$ before it can be collisionally stabilized. So at low pressures, this provides a barrierless path for the overall reaction $\mathrm{Al}+\mathrm{HCl} \rightarrow \mathrm{AlCl}+$ $\mathrm{H}$. The direct reaction path for $\mathrm{Al}+\mathrm{HCl} \rightarrow \mathrm{AlCl}+\mathrm{H}$ has an energetic barrier of about $4 \mathrm{kcal} / \mathrm{mol}$. This is generally consistent with the kinetics observed by Rogowski et al. ${ }^{2}$ In their experiments, both the direct reaction of $\mathrm{Al}+\mathrm{HCl}$ to give $\mathrm{AlCl}$ $+\mathrm{H}$ and the reaction proceeding through chemically activated $\mathrm{AlHCl}$ may have been occurring. They did not observe any pressure dependence in their experiments from 12 to 40 Torr, but it is likely that the reaction proceeding through chemically activated $\mathrm{AlHCl}$ is in the low-pressure limit for these conditions, and in the low-pressure limit, its rate should be independent of pressure. The small positive activation energy measured by Rogowski et al. $(1.6 \mathrm{kcal} / \mathrm{mol})$ is between the value that would be expected for the direct abstraction with a $4 \mathrm{kcal} / \mathrm{mol}$ energetic barrier and the near-zero value that would be expected for the barrierless reaction proceeding through chemically activated $\mathrm{AlHCl}$. So our results are generally consistent with the experi- ments of Rogowski et al. A quantitative comparison between our calculations and their results would require detailed master equation treatment of the chemically activated process (with a variational selection of the transition state) in parallel with the direct abstraction reaction. $\mathrm{AlH}+\mathrm{Cl}$ can react without an energetic barrier to give $\mathrm{Al}+\mathrm{HCl}, \mathrm{AlCl}+\mathrm{H}$, or $\mathrm{AlHCl}$. The reaction to produce $\mathrm{AlHCl}$ is a simple radical recombination reaction. Barrierless paths for the other two reactions were identified on the basis of potential energy surface scans at the UHF/6-31G(d) level.

$\mathbf{A l C l}_{2}$. The $\mathrm{Al}+\mathrm{Cl}_{2}$ reaction was studied experimentally by Rogowski et al. ${ }^{2}$ They measured a rate constant of $7.9 \times 10^{-10}$ $\exp (-780 / T) \mathrm{cm}^{3}$ molecule $\mathrm{s}^{-1}$ for this process. Our computed $\mathrm{AlCl}_{2}$ potential surface is summarized in Figure 2c. Both the addition reaction to give $\mathrm{AlCl}_{2}$ and the $\mathrm{Cl}$ atom transfer reaction to give $\mathrm{AlCl}+\mathrm{Cl}$ are predicted to be barrierless by calculations at the UHF/6-31G(d) level. For the atom transfer reaction, barrierless paths from $\mathrm{Al}+\mathrm{Cl}_{2}$ to $\mathrm{AlCl}+\mathrm{Cl}$ were identified at the UHF/6-31G(d), UMP2(full)/6-31G(d), UB3LYP/6-31G(d), and $\mathrm{UHF} / 6-311+\mathrm{G}(3 \mathrm{df}, 2 \mathrm{p})$ levels of calculation. As a rule, the UHF and UMP2 calculations tend to overpredict barrier heights, so we do not expect that higher-level calculations would reveal an electronic energy barrier. Our computational results at first appear to be inconsistent with Rogowski et al.'s observation of 
(a)

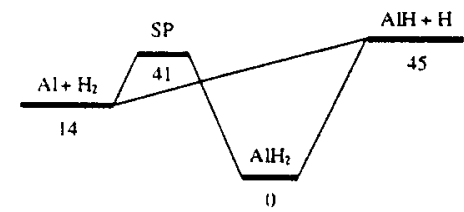

(d)

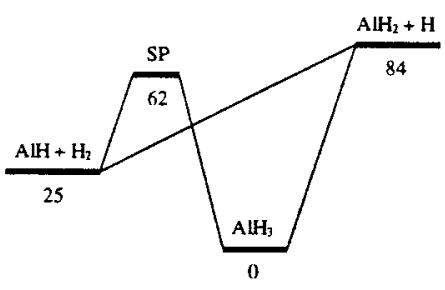

(g)

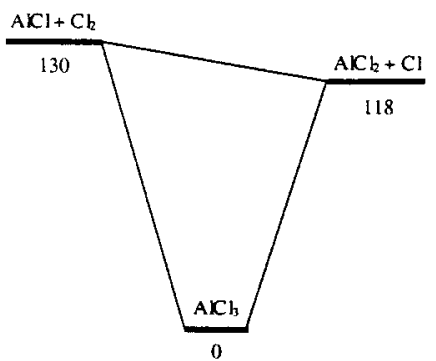

(j)

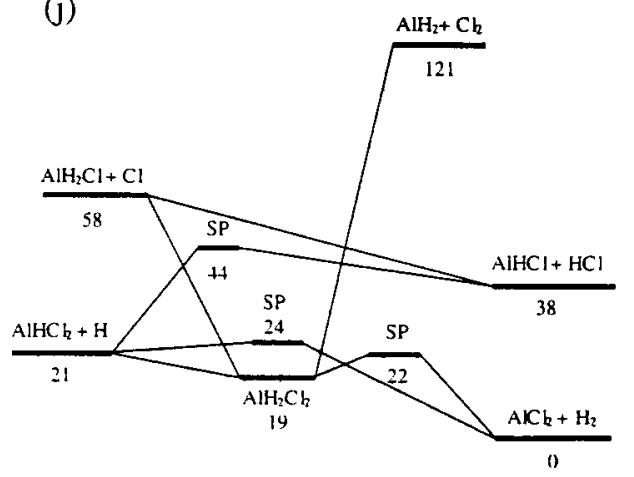

(b)

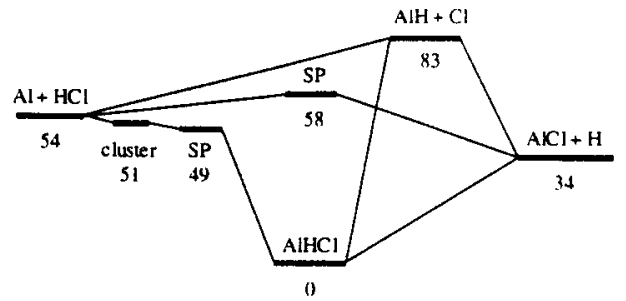

(c)

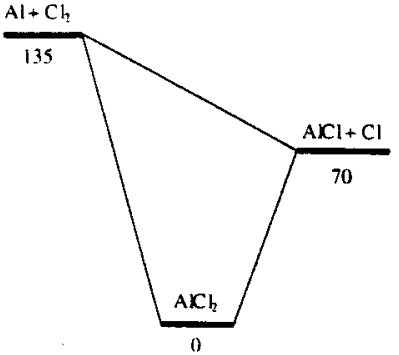

(e)

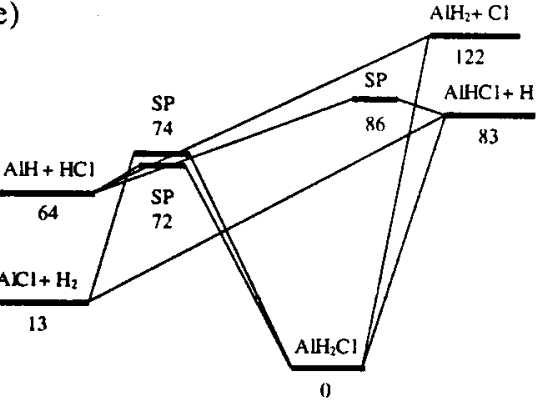

(h)

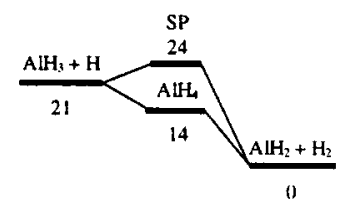

(k)

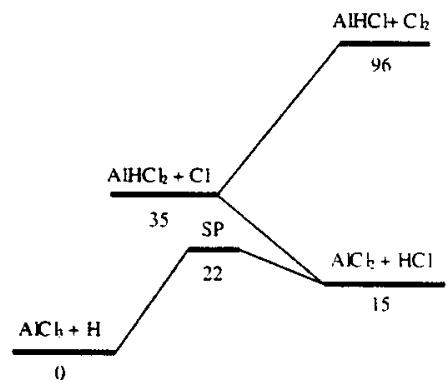

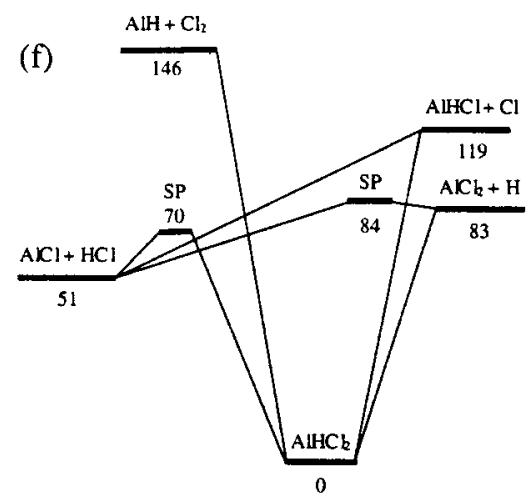

(i)

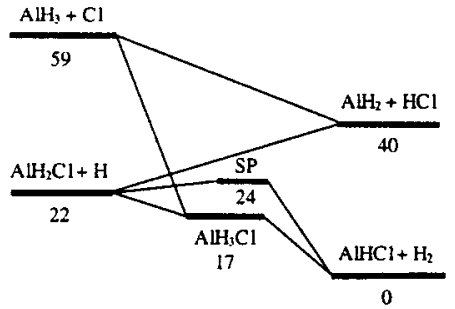

(1)

Figure 2. Schematic energy diagrams for the $\mathrm{Al}-\mathrm{H}-\mathrm{Cl}$ system. Energies are in $\mathrm{kcal} / \mathrm{mol}$ at $0 \mathrm{~K}$, are relative to the lowest-energy structure of each stoichiometry, and are based on calculations using the CBS-RAD method. SP indicates a first-order saddle point on the potential surface.

a positive activation energy for this reaction. However, as underlined by Dean and Bozzelli, ${ }^{23}$ a temperature exponent of 1.5 is expected for an atom abstraction from a stable species by an atom. If this temperature exponent is held fixed, the experimental data can be fit by $1.23 \times 10^{-14} \mathrm{~T}^{1.5} \exp (+74 / T)$ $\mathrm{cm}^{3}$ molecule $\mathrm{s}^{-1} \mathrm{~s}^{-1}$ with accuracy comparable to that of the Arhennius fit presented by Rogowski et al. Our prediction of a zero or slightly negative activation energy for this reaction is thus consistent with the experimental data when the expected temperature dependence of the pre-exponential factor is taken into account.

$\mathrm{AlH}_{3}$. Our computed potential surface for $\mathrm{AlH}_{3}$ is summarized in Figure 2d. Note that no CBS-Q or G-2 calculations were possible for the $\mathrm{AlH}+\mathrm{H}_{2} \leftrightarrow \mathrm{AlH}_{3}$ transition state. The restricted Hartree-Fock wave function for this transition state had an RHF to UHF instability. The insertion of $\mathrm{AlH}$ into $\mathrm{H}_{2}$ to give $\mathrm{AlH}_{3}$ is predicted to have a substantial energetic barrier (about 37 $\mathrm{kcal} / \mathrm{mol}$ ). This is generally consistent with the experimental results of Pasternack and Rice, ${ }^{1}$ who attempted to study this reaction at $300 \mathrm{~K}$. They were unable to observe any reaction of $\mathrm{AlH}$ with $\mathrm{H}_{2}$ but measured a rate constant near the lower limit of their experiment's resolution for the reaction of $\mathrm{AlH}$ with $\mathrm{D}_{2}$. On the basis of the lower detection limit of their experiments, they derived an upper limit of $10^{-14}$ molecule ${ }^{-1} \mathrm{~cm}^{3}$ $\mathrm{s}^{-1}$ for the bimolecular rate constant of the $\mathrm{AlH}+\mathrm{H}_{2}$ reaction. This suggests that there is a barrier of at least $7-10 \mathrm{kcal} / \mathrm{mol}$ 
for this reaction but does not support or contradict the much larger barrier predicted by our calculations. If their measured rate constant for the $\mathrm{Al}+\mathrm{D}_{2}$ reaction of $1.4 \times 10^{-14}$ molecule ${ }^{-1}$ $\mathrm{cm}^{3} \mathrm{~s}^{-1}$ at 460 Torr and $300 \mathrm{~K}$ in argon is correct, it would imply a barrier to reaction substantially smaller than the $37 \mathrm{kcal} /$ mol predicted here. However, they state that their measured value is "near the limit of detectability of these experiments", and we should not therefore rule out the possibility that the barrier to reaction is much larger than would be expected on the basis of that measurement. The $\mathrm{AlH}_{2}+\mathrm{H} \leftrightarrow \mathrm{AlH}+\mathrm{H}_{2}$ reaction is predicted to be barrierless on the basis of scans of the potential energy surface. At the UHF/6-31G(d) level, there is a small barrier (about $2 \mathrm{kcal} / \mathrm{mol}$ ) for this process, but at the UB3LYP/6-31G(d) and UMP2/6-31G(d) levels, barrierless paths from the reactants to products were identified.

$\mathbf{A l H}_{2} \mathbf{C l}$. The computed potential surface for $\mathrm{AlH}_{2} \mathrm{Cl}$ is shown schematically in Figure 2e. To our knowledge, reactions on this surface have not previously been studied experimentally or theoretically. For all three transition-state structures included in this diagram, the restricted Hartree-Fock wave function had an RHF to UHF instability, and the CBS-Q and G-2 methods were therefore not applied. Insertion of $\mathrm{AlH}$ into $\mathrm{HCl}$ is predicted to have a significant energetic barrier (about $8 \mathrm{kcal} /$ mol), but insertion of $\mathrm{AlCl}$ into $\mathrm{H}_{2}$ is predicted to have a much larger barrier (about $61 \mathrm{kcal} / \mathrm{mol}$ ). From the point of view of $\mathrm{AlH}_{2} \mathrm{Cl}$ decomposition, this means that although $\mathrm{H}_{2}$ elimination is much more thermodynamically favorable than $\mathrm{HCl}$ elimination, $\mathrm{HCl}$ elimination has a smaller energetic barrier to reaction. $\mathrm{HCl}$ elimination also proceeds through a slightly "looser" transition state than $\mathrm{H}_{2}$ elimination, as can be seen from the vibrational frequencies and moments of inertia for these transition states shown in Table 2. This situation is strikingly similar to the corresponding $\mathrm{HCl}$ and $\mathrm{H}_{2}$ elimination reactions from $\mathrm{SiH}_{2} \mathrm{Cl}_{2} \cdot{ }^{24-26}$ The two possible $\mathrm{H}$-transfer reactions in this system, $\mathrm{AlHCl}+\mathrm{H} \leftrightarrow \mathrm{AlCl}+\mathrm{H}_{2}$ and $\mathrm{AlH}_{2}+\mathrm{Cl} \leftrightarrow \mathrm{AlH}+$ $\mathrm{HCl}$, are both predicted to be barrierless by potential energy surface scans, from which we identified barrierless reaction paths at the $\mathrm{UHF} / 6-31 \mathrm{G}(\mathrm{d})$ level. The $\mathrm{Cl}$-atom transfer reaction, $\mathrm{AlHCl}$ $+\mathrm{H} \leftrightarrow \mathrm{AlH}+\mathrm{HCl}$, is predicted to have a small energetic barrier (about $3 \mathrm{kcal} / \mathrm{mol}$ ).

$\mathbf{A l H C l}_{2}$. The computed potential surface for $\mathrm{AlHCl}_{2}$ is summarized in Figure 2f. The $\mathrm{AlCl}+\mathrm{HCl} \leftrightarrow \mathrm{AlCl}_{2}+\mathrm{H}$ reaction was studied experimentally by Slavejkov and Fontijn ${ }^{3}$, who measured the rate constant to be $1.1 \times 10^{-11} \exp (-13100 \mathrm{~K} /$ T) $\mathrm{cm}^{3}$ molecule $\mathrm{s}^{-1} \mathrm{~s}^{-1}$ between 1330 and $1610 \mathrm{~K}$ at total pressures of 30 to $80 \mathrm{mbar}$. They did not observe any pressure dependence of the reaction rate over this limited pressure range. Their experimental activation energy of about $26 \mathrm{kcal} / \mathrm{mol}$ is significantly smaller than our predicted energetic barrier of 33 $\mathrm{kcal} / \mathrm{mol}$ for this bimolecular reaction. However, if some of the chemically activated $\mathrm{AlHCl}_{2}$ that should also be formed from $\mathrm{AlCl}+\mathrm{HCl}$ was either being collisionally stabilized or decomposing to $\mathrm{AlCl}_{2}+\mathrm{H}$ rather than back to the reactants, the apparent activation energy would be lowered. Our predicted energetic barrier for $\mathrm{AlCl}+\mathrm{HCl} \leftrightarrow \mathrm{AlHCl}_{2}$ is about $19 \mathrm{kcal} /$ mol. It should also be noted that their measured activation energy is substantially smaller than the endothermicity for $\mathrm{AlCl}+\mathrm{HCl}$ $\leftrightarrow \mathrm{AlCl}_{2}+\mathrm{H}$ predicted by our calculations. The $\mathrm{H}$-atom transfer from $\mathrm{AlHCl}$ to $\mathrm{Cl}$ is predicted to be barrierless. A barrierless path for this reaction was identified on the basis of potential energy surface scans at the UHF/6-31G(d) level of calculation. The insertion of $\mathrm{AlH}$ into $\mathrm{Cl}_{2}$ is predicted to occur without a barrier on the basis of the large exothermicity of this reaction. However, we were unable to identify either a well-defined transition state or a barrierless path for this reaction at the UHF/ 6-31G(d), UMP2/6-31G(d), and UB3LYP/6-31G(d) levels of calculation. Potential surface scans at these levels produced surfaces that were not smooth but that had apparent discontinuities in slope. In constructing these surfaces, we took great care to ensure that the wave function at each geometry was stable with respect to small perturbations. In many cases, the calculations first converged to wave functions with instabilities. In these scans, the $\mathrm{Al}-\mathrm{Cl}$ distance and $\mathrm{Cl}-\mathrm{Cl}$ distance were scanned, while the $\mathrm{Al}-\mathrm{H}$ distance was held fixed and the geometry was restricted to $C_{2 v}$ symmetry. It is not clear whether the apparent discontinuities would disappear if these restrictions were removed.

$\mathbf{A l C l}_{3}$. The potential surface for $\mathrm{AlCl}_{3}$ is summarized in Figure $2 \mathrm{~g}$. The $\mathrm{AlCl}+\mathrm{Cl}_{2} \rightarrow \mathrm{AlCl}_{2}+\mathrm{Cl}$ reaction was studied experimentally by Rogowski et al. ${ }^{2}$ Their measured rate constant for this reaction for temperatures from 400 to $1025 \mathrm{~K}$ was 9.6 $\times 10^{-11} \exp (-610 K / T) \mathrm{cm}^{3}$ molecule $\mathrm{s}^{-1}$. At the UHF/6$31 \mathrm{G}(\mathrm{d})$ and QCISD/6-31G(d) levels of calculation, an energetic barrier is predicted for this reaction, while at the UB3LYP/6$31 \mathrm{G}(\mathrm{d})$ level, a scan of the potential surface shows the reaction to be barrierless. When the energies are computed at higher levels and with larger basis sets and when the zero-point energy is included, the saddle point found at the UHF/6-31G(d) and QCISD/6-31G(d) levels is substantially lower in energy than $\mathrm{AlCl}+\mathrm{Cl}_{2}$. As shown in Table 1 , at the CBS-RAD level of calculation, this point is $8 \mathrm{kcal} / \mathrm{mol}$ lower in energy than the separated reactants. So our calculations lead us to conclude that this reaction is barrierless. As was the case for the $\mathrm{Al}+\mathrm{Cl}_{2}$ reaction, our results at first appear to be inconsistent with the positive activation energy measured by Rogowski et al. According to Dean and Bozzelli, ${ }^{23}$ a temperature exponent near 2 is expected for an atom abstraction from a stable species by a diatomic radical. The experimental data can be fit well by 3.28 $\times 10^{-17} \mathrm{~T}^{2} \exp (+574 / T) \mathrm{cm}^{3}$ molecule $\mathrm{e}^{-1} \mathrm{~s}^{-1}$ with an accuracy similar to that obtained with the Arrhenius fit given by Rogowski et al. Our prediction of a negative activation energy for this reaction is therefore consistent with the experimental data. The insertion of $\mathrm{AlCl}$ into $\mathrm{Cl}_{2}$ is predicted to occur without a barrier on the basis of the large exothermicity of this reaction. However, we were unable to identify either a well-defined transition state or a barrierless path for this reaction at the UHF/6-31G(d), UMP2/6-31G(d), and UB3LYP/6-31G(d) levels of calculation. The situation was identical to that described above for the insertion of $\mathrm{AlH}$ into $\mathrm{Cl}_{2}$.

$\mathbf{A l H}_{4}$. The computed potential surface for $\mathrm{AlH}_{4}$ is shown schematically in Figure $2 \mathrm{~h}$. We are not aware of any previous experimental or theoretical studies of these reactions. At the UHF/6-31G(d), MP2/6-31G(d), and QCISD/6-31G(d) levels of calculation, $\mathrm{AlH}_{4}$ is a local minimum on the potential surface, and a transition state for its decomposition to $\mathrm{AlH}_{2}+\mathrm{H}_{2}$ can be identified. However, as shown in Table 1, when the energies are computed at higher levels and with larger basis sets and when the zero-point energy is included, this transition state becomes lower in energy than $\mathrm{AlH}_{4}$. Thus this reaction is barrierless. The $\mathrm{AlH}_{3}+\mathrm{H} \rightarrow \mathrm{AlH}_{4}$ reaction is not a simple radical recombination, since $\mathrm{AlH}_{3}$ is a closed-shell molecule. Therefore, we cannot simply assume that this reaction is barrierless. At the UHF/6-31G(d) and MP2/6-31G(d) levels of calculation, a barrier is predicted. However, these levels of calculation also predict that this reaction is exothermic rather than endothermic, as predicted by higher-level calculations. Calculations at the UB3LYP/6-31G(d) level correctly predict that the reaction is exothermic. A potential surface scan at this 
level predicts that there is no energetic barrier for this reaction. Calculations at the UQCISD/6-31G(d) level also correctly predict that the reaction is exothermic, but they do predict a barrier. As shown in Table 1, when the energies are computed at higher levels and with larger basis sets and when the zeropoint energy is included, this transition state becomes slightly lower in energy than the reactants. Therefore, we also predict that this reaction is barrierless. Combined with the barrierless decomposition of $\mathrm{AlH}_{4}$ to $\mathrm{AlH}_{2}+\mathrm{H}_{2}$, this provides a rather indirect but barrierless reaction path for the overall reaction $\mathrm{AlH}_{3}$ $+\mathrm{H} \rightarrow \mathrm{AlH}_{2}+\mathrm{H}_{2}$. As shown in Table 1 and Figure 2, a direct reaction path for $\mathrm{AlH}_{3}+\mathrm{H} \rightarrow \mathrm{AlH}_{2}+\mathrm{H}_{2}$ was also identified, with an energetic barrier of about $3 \mathrm{kcal} / \mathrm{mol}$.

$\mathrm{AlH}_{3} \mathbf{C l}$. The computed potential surface for $\mathrm{AlH}_{3} \mathrm{Cl}$ is shown schematically in Figure 2i. It is similar to that for $\mathrm{AlH}_{4}$. At the UHF/6-31G(d), MP2/6-31G(d), and QCISD/6-31G(d) levels of calculation, $\mathrm{AlH}_{3} \mathrm{Cl}$ is a local minimum on the potential surface, and a transition state for its decomposition to $\mathrm{AlHCl}+\mathrm{H}_{2}$ can be identified. However, as shown in Table 1, when the energies are computed at higher levels and with larger basis sets and when zero-point energy is included, this saddle point becomes approximately equal in energy to $\mathrm{AlH}_{3} \mathrm{Cl}$. Thus this reaction has no significant energetic barrier. The $\mathrm{AlH}_{2} \mathrm{Cl}+\mathrm{H} \rightarrow \mathrm{AlH}_{3}-$ $\mathrm{Cl}$ reaction is also predicted to be barrierless. At the UHF/631G(d), MP2/6-31G(d), and QCISD/6-31G(d) levels of calculation, a barrier is predicted for this reaction. However, these levels of calculation also predict that this reaction is exothermic rather than endothermic, as predicted by higher-level calculations. Calculations at the UB3LYP/6-31G(d) level correctly predict that the reaction is exothermic. A potential surface scan at this level predicts that there is no energetic barrier for this reaction. As shown in Table 1, when the energies are computed at higher levels and with larger basis sets and when the zeropoint energy is included, this saddle point becomes lower in energy than the reactants. Therefore, we also predict that this reaction is barrierless. Combined with the barrierless decomposition of $\mathrm{AlH}_{3} \mathrm{Cl}$ to $\mathrm{AlHCl}+\mathrm{H}_{2}$, this provides a barrierless reaction path for the overall reaction $\mathrm{AlH}_{2} \mathrm{Cl}+\mathrm{H} \rightarrow \mathrm{AlHCl}+$ $\mathrm{H}_{2}$. As shown in Table 1 and Figure 2, a direct reaction path for $\mathrm{AlH} \mathrm{H}_{2} \mathrm{Cl}+\mathrm{H} \rightarrow \mathrm{AlHCl}+\mathrm{H}_{2}$ was also identified, with an energetic barrier of about $2 \mathrm{kcal} / \mathrm{mol}$. The $\mathrm{Cl}$-atom transfer reaction $\mathrm{AlH}_{2}+\mathrm{HCl} \rightarrow \mathrm{AlH}_{2} \mathrm{Cl}+\mathrm{H}$ has a small energetic barrier and well-defined saddle point on the reaction path at the UHF/6-31G(d), MP2/6-31G(d), B3LYP/6-31G(d), and QCISD/6-31G(d) levels. However, when the zero-point energy is included and when the energies are calculated at higher levels of theory and with larger basis sets, this saddle point becomes slightly lower in energy than the reactants. Thus, this reaction is also predicted to be barrierless. The association reaction $\mathrm{AlH}_{3}$ $+\mathrm{Cl} \rightarrow \mathrm{AlH}_{3} \mathrm{Cl}$ is predicted to be barrierless by scans of the potential energy surface at the UB3LYP/6-31G(d) level. At the UHF/6-31G(d) and UMP2/6-31G(d) levels, we were unable to find either a saddle point connecting the reactants and products or a barrierless path connecting them. However, on the basis of the UB3LYP/6-31G(d) results, we predict that this reaction is barrierless. The $\mathrm{H}$-atom transfer reaction $\mathrm{AlH}_{3}+\mathrm{Cl} \rightarrow \mathrm{AlH}_{2}$ $+\mathrm{HCl}$ was found to be barrierless on the basis of scans of the potential energy surface at the UHF/6-31G(d) level.

$\mathbf{A l H}_{2} \mathbf{C l}_{2}$. The computed potential surface for $\mathrm{AlH}_{2} \mathrm{Cl}_{2}$ is summarized in Figure $2 \mathrm{i}$. $\mathrm{AlH}_{2} \mathrm{Cl}_{2}$ is a first-order saddle point at the UHF/6-31G(d) level of theory but a local minimum at the UB3LYP/6-31G(d), UMP2/6-31G(d), and UQCISD/6-31G(d) levels of theory. Its decomposition to $\mathrm{AlCl}_{2}+\mathrm{H}_{2}$ is predicted to have an energetic barrier at all of the levels of theory considered here. This barrier is about $3 \mathrm{kcal} / \mathrm{mol}$ at the CBSRAD level of calculation. At the UHF/6-31G(d) level, where $\mathrm{AlH}_{2} \mathrm{Cl}_{2}$ is a first-order saddle point, the imaginary frequency corresponds to the decomposition of $\mathrm{AlH}_{2} \mathrm{Cl}_{2}$ to $\mathrm{AlHCl}_{2}+\mathrm{H}$. The $\mathrm{AlHCl}_{2}+\mathrm{H}$ association reaction that forms $\mathrm{AlH}_{2} \mathrm{Cl}_{2}$ is predicted to be endothermic by calculations at the UHF/6-31G(d), UMP2/6-31G(d), and UQCISD/6-31G(d) levels. However, it is predicted to be exothermic by calculations at the UB3LYP/ 6-31G(d) level, as well as by the higher-level calculations whose results are shown in Table 1 . At the UHF/6-31G(d) level, this reaction is predicted to be barrierless, while at the UMP2/631G(d) and UQCISD/6-31G(d) levels, it has a barrier, and a transition state for the reaction was located. As shown by the CBS-RAD calculation in Table 1 , however, when higher-level methods are used, this saddle point becomes slightly lower in energy than the reactants. As was the case for the analogous reactions in the $\mathrm{AlH}_{4}$ and $\mathrm{AlH}_{3} \mathrm{Cl}$ systems, this reaction is predicted to be barrierless. The direct $\mathrm{H}$-atom transfer reaction $\mathrm{AlHCl}_{2}+\mathrm{H} \rightarrow \mathrm{AlCl}_{2}+\mathrm{H}$ is predicted to have about a $3 \mathrm{kcal} /$ mol energetic barrier. However, the $\mathrm{H}$-atom transfer reaction $\mathrm{AlH}_{2} \mathrm{Cl}+\mathrm{Cl} \rightarrow \mathrm{AlHCl}+\mathrm{HCl}$ is predicted to be barrierless on the basis of potential energy surface scans at the UHF/6-31G(d) level. The $\mathrm{Cl}$-atom transfer reaction $\mathrm{AlHCl}+\mathrm{HCl} \rightarrow \mathrm{AlHCl}_{2}$ $+\mathrm{H}$ is predicted to have approximately a $6 \mathrm{kcal} / \mathrm{mol}$ energetic barrier. The association reaction $\mathrm{AlH}_{2} \mathrm{Cl}+\mathrm{Cl} \rightarrow \mathrm{AlH}_{2} \mathrm{Cl}_{2}$ is predicted to be barrierless. At the UHF/6-31G(d) and UMP2/ 6-31G(d) levels, we were unable to find either a saddle point or a barrierless path connecting the reactants and products. However, at the UB3LYP/6-31G(d) level, a barrierless reaction path was identified. The situation was the same for the $\mathrm{AlH}_{2}+$ $\mathrm{Cl}_{2} \rightarrow \mathrm{AlH}_{2} \mathrm{Cl}_{2}$ insertion reaction. At the UHF/6-31G(d) and UMP2/6-31G(d) levels, we were unable to find either a saddle point connecting the reactants and products or a barrierless path connecting them. However, at the UB3LYP/6-31G(d) level, a barrierless reaction path was identified.

$\mathbf{A l H C l}_{3}$. The computed potential surface for $\mathrm{AlHCl}_{3}$ is summarized in Figure 2k. In contrast to the other $\mathrm{AlH}_{x} \mathrm{Cl}_{4-x}$ species, $\mathrm{AlHCl}_{3}$ is not a local minimum on the potential energy surface for any of the methods applied here. The $\mathrm{Cl}$-atom transfer reaction $\mathrm{AlCl}_{2}+\mathrm{HCl} \rightarrow \mathrm{AlCl}_{3}+\mathrm{H}$ is predicted to have a significant energetic barrier of about $7 \mathrm{kcal} / \mathrm{mol}$. However, the Cl-atom transfer reaction $\mathrm{AlHCl}+\mathrm{Cl}_{2} \rightarrow \mathrm{AlHCl}_{2}+$ $\mathrm{Cl}$, which is much more exothermic, is predicted by potential energy surface scans at the UHF/6-31G(d) level to be barrierless. The $\mathrm{H}$-atom transfer reaction $\mathrm{AlHCl}_{2}+\mathrm{Cl} \rightarrow \mathrm{AlCl}_{2}+\mathrm{HCl}$ has an energetic barrier and a well-defined saddle point on the reaction path at the UHF/6-31G(d), UMP2/6-31G(d), UB3LYP/ 6-31G(d), and UQCISD/6-31G(d) levels of calculation. However, when zero-point energy is included and when the energies are calculated at higher levels of theory and with larger basis sets, this saddle point becomes slightly lower in energy than the reactants. Thus, this reaction is also predicted to be barrierless.

$\mathrm{AlCl}_{4}$. The computed potential surface for $\mathrm{AlCl}_{4}$ is summarized in Figure 21. $\mathrm{AlCl}_{4}$ is predicted by the higher-level calculations to be a stable structure approximately $20 \mathrm{kcal} / \mathrm{mol}$ lower in energy than $\mathrm{AlCl}_{3}+\mathrm{Cl}$. Its formation from $\mathrm{AlCl}_{3}+$ $\mathrm{Cl}$ is predicted to occur without an energetic barrier by potential surface scans at the UHF/6-31G(d) level. At this level, however, the $\mathrm{UHF} / 6-31 \mathrm{G}(\mathrm{d})$ calculations predict that $\mathrm{AlCl}_{4}$ is a first-order saddle point, about $6 \mathrm{kcal} / \mathrm{mol}$ higher in energy than $\mathrm{AlCl}_{3}+$ $\mathrm{Cl}$. The $\mathrm{Cl}$-atom transfer reaction $\mathrm{AlCl}_{2}+\mathrm{Cl} \rightarrow \mathrm{AlCl}_{3}+\mathrm{Cl}$ has a small energetic barrier of $2.6 \mathrm{kcal} / \mathrm{mol}$ at the UHF/6-31G(d) level. However, at the UMP2/6-31G(d') level, where a first- 
order saddle point could also be identified, the saddle point was $0.2 \mathrm{kcal} / \mathrm{mol}$ lower in energy than the reactants. We have not carried out higher levels of calculation because of computational expense and difficulties in locating this saddle point on the extremely flat potential surface (the imaginary frequency at the UMP2/6-31G(d') saddle point was only $\left.42 \mathrm{~cm}^{-1}\right)$. However, since the UHF and UMP2 calculations tend to overestimate barrier heights in general, we can safely conclude that there is no energetic barrier to this reaction. Our calculations for the insertion of $\mathrm{AlCl}_{2}$ into $\mathrm{Cl}_{2}$ to give $\mathrm{AlCl}_{4}$ gave results similar to those for the insertion of $\mathrm{AlH}$ and $\mathrm{AlCl}$ into $\mathrm{Cl}_{2}$. We were unable to locate either a well-defined transition state or a completely barrierless path from $\mathrm{AlCl}_{2}+\mathrm{Cl}_{2}$ to $\mathrm{AlCl}_{4}$. Again there were apparent discontinuities in the slope of the potential energy surface when the $\mathrm{Al}-\mathrm{Cl}$ and $\mathrm{Cl}-\mathrm{Cl}$ bond lengths were varied holding other bond lengths and angles fixed. However, a nonsmooth path from $\mathrm{AlCl}_{2}+\mathrm{Cl}_{2}$ to $\mathrm{AlCl}_{4}$ was found with a maximum energy only about $4 \mathrm{kcal} / \mathrm{mol}$ above that of $\mathrm{AlCl}_{2}+$ $\mathrm{Cl}_{2}$ at the UHF/6-31G(d) level. It is likely that at higher levels of calculation and with no bond lengths or angles constrained, this apparent barrier would disappear, as we have observed for many of the other reactions studied here. We therefore predict that this reaction is barrierless as well, though we have not actually shown that to be the case.

\section{Summary and Conclusions}

High-level ab initio quantum chemical calculations have been used to investigate possible reactions in the $\mathrm{Al}-\mathrm{H}-\mathrm{Cl}$ system. Transition states or barrierless reaction paths have been identified for essentially all feasible reactions in this system involving a single aluminum atom. These results provide a basis for the estimation of reaction rate parameters for this system using transition state theory and related unimolecular reaction rate theories, thereby constructing a reaction mechanism useful for detailed chemical kinetic modeling of aluminum combustion in $\mathrm{HCl}$ and chemical vapor deposition processes using $\mathrm{AlCl}_{3}$ in $\mathrm{H}_{2}$. In the few cases where previous experimental or theoretical results have been published, the present work is consistent with previous work.

Acknowledgment. This research was partially supported by generous grants of computer time from the University at Buffalo (SUNY) Center for Computational Research, which are grate- fully acknowledged. L.C. wishes to thank Dr. Pierre Florian from CRMHT-CNRS, Orleans, for valuable discussions.

\section{References and Notes}

(1) Rogowski, D. F.; Marshall, P.; Fontijn, A. J. Phys. Chem. 1989, 93, 1118-1123.

(2) Pasternack, L.; Rice, J. K. J. Phys. Chem. 1991, 95, 8701-8706.

(3) Slavejkov, A. G.; Fontijn, A. Chem. Phys. Lett. 1990, 165, 375378.

(4) Sakai, S. J. Phys. Chem. 1992, 96, 8369-8373.

(5) Fängström, T.; Lunell, S.; Kasai, P. H.; Eriksson, L. A. J. Phys. Chem. A 1998, 102, 1005-1017.

(6) Swihart, M. T.; Catoire, L. Combust. Flame 2000, 121, 210-222.

(7) Catoire, L.; Swihart, M. T.; Legrand, B.; Gökalp, I.; Paillard, C. Combust. Flame, submitted for publication.

(8) Becke, A. D. Phys. Rev. A 1988, 38, 3098

(9) Lee, C.; Yang, W.; Parr, R. G. Phys. Rev. B 1988, 37, 785.

(10) Becke, A. D. J. Chem. Phys. 1993, 98, 5648.

(11) Ochterski, J. W.; Petersson, G. A.; Wiberg, K. B. J. Am. Chem. Soc. 1995, 117, 11299-11308.

(12) Curtiss, L. A.; Raghavachari, K.; Trucks, G. W.; Pople, J. A. J. Chem. Phys. 1991, 94, 7221-7230.

(13) Curtiss, L. A.; Raghavachari, K.; Pople, J. A. J. Chem. Phys. 1993, 98, 1293-1298.

(14) Curtiss, L. A.; Redfern, P. C.; Smith, B. J.; Radom, L. J. Chem. Phys. 1996, 104, 5148-5152.

(15) Frisch, M. J.; Trucks, G. W.; Schlegel, H. B.; Gill, P. M. W.; Johnson, B. G.; Robb, M. A.; Cheeseman, J. R.; Kieth, T.; Petersson, G. A.; Montgomery, J. A.; Raghavachari, K.; Al-Laham, M. A.; Zakrzewski, V. G.; Ortiz, J. V.; Foresman, J. B.; Cioslowski, J.; Stefanov, B. B.; Nanayakkara, A.; Challacombe, M.; Peng, C. Y.; Ayala, P. Y.; Chen, W.; Wong, M. W.; Andres, J. L.; Replogle, E. S.; Gomperts, R.; Martin, R. L.; Fox, D. J.; Binkley, J. S.; Defrees, D. J.; Baker, J.; Stewart, J. P.; HeadGordon, M.; Gonzalez, C.; Pople, J. A. Gaussian 94, Revision E.2; Gaussian, Inc.: Pittsburgh, PA, 1995.

(16) Mayer, P. M.; Parkinson, C. J.; Smith, D. M.; Radom, L. J. Chem. Phys. 1998, 108, 604-615.

(17) Chuang, Y.-Y.; Coitino, E. L.; Truhlar, D. G. J. Phys. Chem. A 2000, 104, 446-450.

(18) Allendorf, M. D.; Melius, C. F. Proc. Electrochem. Soc. 1999, 98 $23,28-33$.

(19) Allendorf, M. D.; Melius, C. F.; Bauschlicher, C. W., Jr. J. Phys. IV (France) 1999, 9, 23-31.

(20) Scott, A. P.; Radom, L. J. Phys. Chem. 1996, 100, 16502-16513.

(21) Senger, S.; Radom, L. J. Phys. Chem. A 2000, 104, 7375-7385.

(22) Chase, M. W., Jr. J. Phys. Chem. Ref. Data 1998, Monograph 9 , $1-1951$.

(23) Dean, A. M.; Bozzelli, J. W. In Gas-Phase Combustion Chemistry; Gardiner, W. C., Jr., Ed.; Springer-Verlag: New York, 2000; pp 125-341

(24) Su, M.-D.; Schlegel, H. B. J. Phys. Chem. 1993, 97, 9981-9985.

(25) Wittbrodt, J. M.; Schlegel, H. B. Chem. Phys. Lett. 1997, 265, 527531.

(26) Swihart, M. T.; Carr, R. W. J. Phys. Chem. A 1998, 102, 1542- 